\title{
Civil Penalties under Section 5(m) of the Federal Trade Commission Act
}

\begin{abstract}
David O. Bickart $\dagger$
Section $5(m)$ of the Federal Trade Commission Act promises to greatly enhance the Commission's consumer protection role. For the first time in its history, the FTC is empowered to enforce the law of deceptive trade practices, embodied in its rules and case determinations, through civil penalty actions against firms that are not themselves subject to Commission cease and desist orders. It is far from clear, however, how section $5(\mathrm{~m})$ will work in practice, for the statute is ambiguous on many important questions and silent on others. In this article $M r$. Bickart identifies and examines certain major problems with the statute that the courts and the Commission will soon confront.
\end{abstract}

On January 4, 1975, the Magnuson-Moss Warranty-Federal Trade Commission Improvement Act ${ }^{1}$ became law. Passage of Title II of the Act ${ }^{2}$ marked the most ambitious attempt to enhance the authority of the Federal Trade Commission since the passage of its organic statute in 1914. In addition to expanding the Commission's authority to seek preliminary injunctions, ${ }^{3}$ the Magnuson-Moss Act appeared to provide the Commission with every major item on its legislative shopping list in the consumer protection area. The Commission's subject-matter jurisdiction, long an uncertain question, was clarified to apply to acts or practices "affecting" as well as "in" commerce. ${ }^{4}$ Explicit authority was given to the Commission to pro-

$\dagger$ Deputy General Counsel, United States Environmental Protection Agency. This article was written while the author was a Victor $\mathrm{H}$. Kramer Fellow at the University of Chicago Law School, on leave from the Federal Trade Commission, Bureau of Consumer Protection. The article does not reflect the views of either the Bureau or the Federal Trade Commission.

1 Pub. L. No. 93-637, 88 Stat. 2183 (1975) (codified in scattered sections of 15 U.S.C.).

2 For a discussion of Title I, which comprises the Act's warranty provisions, see Roths. child, The Magnuson-Moss Warranty Act: Does it Balance Warrantor and Consumer Interests?, 44 GEO. WASH. L. REv. 335 (1976).

3 Pub. L. No. 93-153, tit. IV, § 408(f), 87 Stat. 592 (1974) (codified at 15 U.S.C. § 53(b) (Supp. IV 1974)).

$\checkmark$ Magnuson-Moss Warranty-Federal Trade Commission Improvement Act, Pub. L. No. 93-637, tit. II, § 201(a), 88 Stat. 2193 (1975). In FTC v. Bunte Bros. Inc., 312 U.S. 349 (1941), the Supreme Court held the "in commerce" language insufficient to sustain FTC jurisdiction over intrastate sales. Whether the Bunte decision really hampered the FTC or merely provided it with an excuse for inaction was a source of some controversy before the passage of the Magnuson-Moss Act. Compare Note, Jurisdictional Fetter on the FTC, 76 YALE L.J. 1688 
mulgate substantive trade regulation rules ${ }^{5}$ in the consumer protection area. The Commission was empowered to bring civil actions in federal district courts for a variety of forms of "redress" to benefit consumers who had been injured by acts or practices which the Commission had found to be unfair or deceptive. ${ }^{6}$ Finally, the Commission was authorized, under some circumstances, to seek civil penalties in district court against parties not themselves subject to an outstanding Commission cease and desist order. ${ }^{7}$

Unlike its companion sections concerning rulemaking and consumer redress, the civil penalty provision attracted little attention, and little thought appears to have been given to how the provision would work. Indeed, what little explanation was given by the provision's sponsors was generally opaque and sometimes misdirected. The resulting provision is rife with interpretative problems that the Commission, potential defendants, and, ultimately, the courts will have to face. Whether it will prove a useful addition to the Commission's new arsenal of enforcement powers, or just another empty weapon, ${ }^{8}$ remains to be seen. This article will attempt to identify at least some of the issues that must ultimately be resolved.

\section{The Genesis of Section 5(M)}

During the sixty years following the passage of the Federal Trade Commission Act in 1914, it was frequently observed that the Commission's remedial authority was inadequate to deter unscru-

(1967), with ABA, Report of CoMm'N To StUdy THE FTC 52-54 (1969) [hereinafter cited as ABA REPORT].

s Magnuson-Moss Warranty-Federal Trade Commission Improvement Act, Pub. L. No. 93-637, tit. II, § 202, 88 Stat. 2193 (1975) (codified at 15 U.S.C. \& 57a (Supp. V 1975)). The FTC's authority to promulgate trade regulation rules under $\S 6(\mathrm{~g})$ of the Federal Trade Commission Act [hereinafter the FTC Act], 15 U.S.C. $\$ 46(\mathrm{~g})$ (1970) had only recently been judicially upheld in National Petroleum Refiners Ass'n v. FTC, 482 F.2d 672 (D.C. Cir. 1973), cert. denied, 415 U.S. 951 (1974).

- Magnuson-Moss Warranty-Federal Trade Commission Improvement Act, Pub. L. No. 93-637, tit. II, \$ 206, 88 Stat. 2201 (1975) (codified at 15 U.S.C. $\$ 57 b$ (Supp. V 1975)). In a case decided shortly before $\S 206$ was enacted, the Ninth Circuit in Heater v. FTC, 503 F.2d 321 (9th Cir. 1974), had held that the FTC was not authorized to order restitution as part of its cease and desist order.

7 Magnuson-Moss Warranty-Federal Trade Commisson Improvement Act, Pub. L. No. 93-637, tit. II, $\S 205,88$ Stat. 2200 (1975) (codified at 15 U.S.C. $\$ 45(\mathrm{~m})$ (Supp. V 1975)).

${ }^{8}$ Although the FTC has been authorized since 1938 to seek injunctions pendente lite against false advertisements for foods, drugs, devices, and cosmetics, FTC Act $\$ 13,15$ U.S.C. $\S 53$ (1970), the FTC sought injunctions in only a handful of cases between 1950 and 1970. Still less frequently invoked has been $\$ 14$ of the FTC Act, 15 U.S.C. $\$ 54$ (1970), also added in 1938, which imposes criminal penalties for false advertising of foods, drugs, devices, and cosmetics when the advertised product may be "injurious to health" or when the ads are made with "intent to mislead or defraud." 
pulous businesses from engaging in deceptive practices. ${ }^{9}$ Although some commentators questioned the wisdom of launching a federal administrative agency on a campaign against hard-core deception, ${ }^{10}$ the social unrest of the late 1960's" and the general dissatisfaction with the existing level of FTC consumer protection activity ${ }^{12}$ fostered a demand for increased federal intervention in preventing deceptive practices.

In 1968, the Senate passed the "Deceptive Sales Act,"13 which would have empowered the FTC to seek preliminary injunctions against a variety of deceptive practices, including, but not limited to, "false advertisements" for food, drugs, devices, and cosmetics for which preliminary injunctions had been authorized by the WheelerLea Amendments of $1938 . .^{14}$ Although the bill received no House action, it was reintroduced by Senators Magnuson and Moss in $1969,{ }^{15}$ along with certain consumer class action legislation, sponsored by Senator Tydings and Congressman Eckhardt. ${ }^{16}$

In his Consumer Message of October, 1969,17 President Nixon called for additional consumer legislation, to be administered by the Justice Department, as well as expanded FTC jurisdiction and preliminary injunction authority. The Nixon Administration bill, ${ }^{18}$ introduced in December, 1969, would have specified eleven categories of conduct as constituting "unfair or deceptive practice(s)" and would have granted jurisdiction to the district courts to enjoin such practices upon application of the Attorney General. The bill would

' E.g., ABA REPORT, supra note 4, at 63-64; Handler, The Wheeler-Lea Amendments, 6 Law \& Contemp. Prob. 91, 105 (1939); see G. Henderson, The federal Trade Commission 231, 232 (1924).

10 E.g., G. Henderson, supra note 9; R. Posner, Regulation of Advertising by the FTC 32 (1973).

"The relationship between ghetto-fraud and riots was suggested by President Nixon's consumer advisor, Virginia $\mathrm{H}$. Knauer, in her testimony supporting additional federal consumer protection legislation. Hearings on H.R. 14931 Before the Subcomm. on Commerce and Finance of the House Comm. on Interstate and Foreign Commerce, 91st Cong., 2d Sess. 195, 197 (1970) [hereinafter cited as 1970 House Hearings].

12 E.g., ABA Report, supra note 4; E. Cox, R. Felimeth \& J. Schultz, The Consumer and the Federal Trade Commission (1969).

is S. 3065, 90th Cong., 1st Sess. (1968).

is FTC Act $\$ 13$, 15 U.S.C. $\$ 53$ (1970) (originally enacted as Act of March 21 , 1938, ch. $49, \S 4,52$ Stat. 114).

15 S. 2246, 91st Cong., 1st Sess. (1969), Hearings on S. 2246, S. 3092 and S. 3201 Before the Consumer Subcomm. of the Senate Comm. on Commerce, 91st Cong. 1st \& 2d Sess. 2 (1970) [hereinafter cited as 1970 Senate Hearings].

16 S. 3092, 91st Cong., 1st Sess. (1969), 1970 Senate Hearings, supra note 15, at 2-4; H.R. 14585, 91st Cong., 1st Sess. (1969), 1970 House Hearings, supra note 11, at 4-5.

17 Special Message to the Congress on Consumer Protection, 1969 Pub. PAPERs 883-88.

Ix S. 3201, 91st Cong., 1st Sess. (1969), 1970 Senate Hearings, supra note 15, at 4-6; H.R. 14931, 91st Cong., 1st Sess. (1969), 1970 House Hearings, supra note 11, at 2-4. 
also have created a federal right of action on behalf of consumers injured by any seller who had been previously enjoined from engaging in the challenged practices by a district court or by the FTC in a section 5 cease and desist proceeding. ${ }^{19}$

In the course of hearings in both houses, the Nixon Administration bill was subjected to extensive criticism because the categories of practices prohibited by the bill were considered too narrow, and many practices that had been previously held to be illegal were not included. ${ }^{20}$ At the same time, however, the Tydings-Eckhardt bill was criticized as imposing potentially heavy penalties for practices that neither the FTC nor the courts had previously held to be illegal. ${ }^{21}$ The FTC, not content with the consumer class action mechanism alone, urged that the Commission be granted authority to impose civil penalties for violations of existing law. ${ }^{22}$

In response to these criticisms, the Senate Commerce Committee's report on consumer class action legislation suggested several major changes to the Nixon Administration's bill. ${ }^{23}$ First, a general category consisting of "any other unfair or deceptive act or practice prohibited by rule or regulation promulgated by the Federal Trade Commission" was added to the list of categories of "unfair consumer practices." Section $6(\mathrm{~g})$ of the FTC Act would have been amended to grant the Commission explicit authority to promulgate trade regulation rules defining unfair or deceptive acts or practices. ${ }^{24} \mathrm{~A}$ second major change suggested was the deletion of the "triggering" provision in the Administration bill which conditioned consumer actions on the existence of an outstanding Commission order or judicial decree against the defendant. Finally, the FTC was authorized to bring a civil penalty action in the district courts against a seller who was knowingly engaged in any of the specified "unfair consumer practices." ${ }^{25}$ The bill, however, received no floor action in the 91st Congress.

In February, 1971, Senators Magnuson and Moss tried a differ-

19 S. 3201, \$ 204, 91st Cong., 1st Sess. (1969), 1970 Senate Hearings, supra note 15, at 5. Under the bill a prior consent decree or order would have provided a predicate for a consumer action, but only litigated judicial decrees were to be accorded prima facie weight; FTC orders, whether issued after litigation or by consent, were not entitled to prima facie weight.

${ }_{20}$ See, e.g., 1970 Senate Hearings, supra note 15 , at $9,36,72,110,120-21,161,297$, and 496-97; 1970 House Hearings, supra note 11, at 173-74, 231-32.

${ }_{21} 1970$ Senate Hearings, supra note 15, at 210, 240, 519; 1970 House Hearings, supra note 11 , at 250 .

221970 Senate Hearings, supra note 15 , at 8-9.

2 S. REP. No. 91-1124, 91st Cong., 2d Sess. (1970).

24 Id. at $13,24$.

25 Id. at 1, 14, 21-22. 
ent legislative tack. Their proposed "Consumer Products Warranties and Federal Trade Commission Improvement Act," S. 986, ${ }^{26}$ deleted the controversial class action provisions and combined the remaining proposals to increase FTC enforcement authority with the relatively uncontroversial warranty legislation that had passed the Senate by a voice vote the previous session. ${ }^{27}$ In place of the class action provision, S. 986 would have empowered the FTC to order various forms of "redress" on behalf of consumers who had been injured by acts or practices that had been made subject to a cease and desist order ${ }^{28}$ With respect to civil penalties, the Commission would have been empowered to bring a district court action against any seller who was engaged in "any act or practice which is unfair or deceptive to a consumer and is prohibited by ... [section 5 of the FTC Act] with actual or implied knowledge that such act is unfair and deceptive and is prohibited [by section 5] . . ."29 The Commission was also specifically authorized to promulgate "legislative rules" defining unfair or deceptive acts or practices." Any practices committed in violation of these rules would, by definition, have been "unfair or deceptive to a consumer," thus, giving rise to potential civil penalties. S. 986 encountered vigorous opposition, but that opposition focused primarily on the consumer redress and rulemaking provisions. ${ }^{31}$ The civil penalty section, like the largely uncontroversial provisions on jurisdiction, injunctions, and enforcement of process, received little attention. S. 986 easily passed the Senate in November, $1971,{ }^{32}$ but the House failed to act on the bill.

In January, 1973, Senators Magnuson and Moss reintroduced their warranty and FTC improvement package in substantially the same form as S. 986. ${ }^{33}$ Although the bill's civil penalty provision, section 202 , was virtually identical with the comparable provision in S. $986,{ }^{34}$ the Senate Commerce Committee deleted the section

${ }_{2 s}$ S. 986, 92d Cong., 1st Sess. (1971), Hearings on S. 986 Before the Consumer Subcomm. of the Senate Comm. on Commerce, 92d Cong., 1st Sess. 3-25 (1971).

${ }^{27} 116$ CoNG. REc. 22487 (1970).

2x S. 986, tit. II, $\$ 203$, 92d Cong., 1st Sess. (1971), Hearings on S. 986, supra note 26, at 19-20.

2 Id. $\$ 202$, Hearings on S. 986, supra note 26, at 18-19.

30 The term "legislative" was used to indicate that valid FTC rules would have the force of law, as distinguished from so-called "interpretative" rules. S. REP. No. 92-269, 92d Cong., 2d Sess. 26 (1971).

I1 See, e.g., Hearings on S. 986, supra note 26, at 122-23, 188-90, 193.

12117 CoNG. Rec. 39876 (1971).

3 S. 356, 93d. Cong., 1st Sess. (1973).

31 The only difference between the two sections was that the word "or" replaced the word "and" in the phrase "unfair or deceptive." 
that would have granted the Commission explicit rulemaking authority. The Commission had expressed concern that a prolonged legislative struggle over rulemaking would imperil the entire legislative package. ${ }^{35}$ In this form, the proposed legislation, S. 356, passed the Senate without any debate on the FTC improvement sections. ${ }^{36}$

While S. 356 was pending in the Senate, the House was considering its own warranty and FTC legislation. H.R. 7917, as passed by the House, contained a rulemaking section but lacked provisions for civil penalties or consumer redress. ${ }^{37}$ However, the House-Senate Conference Committee reinserted, in a modified form, both the rulemaking provision, which had been omitted from the Senate bill, and the consumer redress and civil penalty provisions which had been omitted from the House bill. ${ }^{38}$ The civil penalty provision, section 205(a), which was ultimately passed by both Houses without further amendment, provides:

(m)(1)(A) The Commission may commence a civil action to recover a civil penalty in a district court of the United States against any person, partnership, or corporation which violates any rule under this Act respecting unfair or deceptive acts or practices (other than an interpretive rule or a rule violation of which the Commission has provided is not an unfair or deceptive act or practice in violation of subsection (a)(1)) with actual knowledge or knowledge fairly implied on the basis of objective circumstances that such act is unfair or deceptive and is prohibited by such rule. In such action, such person, partnership, or corporation shall be liable for a civil penalty of not more than $\$ 10,000$ for each violation.

(B) If the Commission determines in a proceeding under subsection (b) that any act or practice is unfair or deceptive, and issues a final cease and desist order with respect to such act or practice, then the Commission may commence a civil action to obtain a civil penalty in a district court of the United

35 S. REp. No. 93-151, 93d Cong., 1st Sess. 57 (1973).

36119 CoNG. REc. 29490 (1973).

${ }^{37}$ H.R. 7917, \$ 202, 93d Cong., 2d Sess. (1973). In the interval between the votes in the Senate and the House, the FTC had won judicial recognition of its rulemaking authority in National Petroleum Refiners' Ass'n v. FTC, 482 F.2d 672 (D.C. Cir. 1973), cert. denied, 415 U.S. 951 (1974). The rulemaking procedures of H.R. 7917 were substantially more elaborate than those which the FTC had previously used. Although H.R. 7917 had originally contained a redress provision, it was stricken in committee and an attempt to reinsert it on the floor was defeated. 120 CoNG. REC. 31735,31737 (1974).

${ }^{3 *}$ SEN. Conf. Rep. No. 93-1408, 93d Cong., 2d Sess. (1974), reprinted in [1974] U.S. Code Cong. \& AD. News 7726. 
States against any person, partnership, or corporation which engages in such act or practice-

(1) after such cease and desist order becomes final (whether or not such person, partnership, or corporation was subject to such cease and desist order), and

(2) with actual knowledge that such act or practice is unfair or deceptive and is unlawful under subsection (a)(1) of this section.

In such action, such person, partnership, or corporation shall be liable for a civil penalty of not more than $\$ 10,000$ for each violation.

(C) In the case of a violation through continuing failure to comply with a rule or with section 5(a)(1), each day of continuance of such failure shall be treated as a separate violation, for purposes of subparagraphs (A) and (B). In determining the amount of such a civil penalty, the court shall take into account the degree of culpability, any history of prior such conduct, ability to pay, effect on ability to continue to do business, and such other matters as justice may require.

(2) If the cease and desist order establishing that the act or practice is unfair or deceptive was not issued against the defendant in civil penalty action under paragraph (1)(B) the issues of fact in such action against such defendant shall be tried de novo.

(3) The Commission may compromise or settle any action for a civil penalty if such compromise or settlement is accompanied by a public statement of its reasons and is approved by the court.

Section 205(a), now section $5(\mathrm{~m})$ of the FTC Act, ${ }^{39}$ draws the distinction, absent from previous versions, between penalty actions brought against persons who violate FTC rules and penalty actions brought against persons who engage in practices that the FTC, in individual caselaw decisions, has held to violate section 5 . For rule violations, liability may be imposed upon a defendant who knows or should have known that his practices violate a rule. In contrast, a defendant who has engaged in practices that the FTC has previously held to be illegal, but that are not prohibited by a rule, must be shown to have had "actual knowledge" both that his practices were unfair or deceptive and that they were unlawful under section 
$5(a)(1)$. For this latter class of defendants, a further distinction is drawn between those defendants who were subject to an FTC cease and desist order prohibiting the acts or practices in question, and those who were not. With respect to a defendant who is subject to a previous order, the Commission's findings of fact in the underlying administrative proceeding are to be "conclusive" in the penalty proceeding "if" supported by substantial evidence." 40 Other defendants, not subject to a previous cease and desist order, are entitled to a "trial de novo" on the factual issues that had been decided by the FTC in the underlying administrative proceeding.

A year after the Magnuson-Moss Act became law, the FTC announced that it had undertaken a pilot program to enforce the civil penalty provisions of the Act. Under this program, the Commission mailed letters to selected businesses informing them of the new statutory provision. Enclosed in each letter was a synopsis of one or more prior FTC decisions that the Commission believed might be applicable to the firm's activities. The recipients were notified that, "in order to avert possible action by the Federal Trade Commission you should immediately insure that you are not engaged in any of the practices proscribed by the enclosed decisions." 41 Follow-up investigations were authorized to determine the existence of any violations by the firms of the principles embodied in the decisions. ${ }^{42}$ At this writing, the pilot program has resulted in the filing of five civil penalty actions under the new section $5(\mathrm{~m}) .^{43} \mathrm{It}$ is reasonable to anticipate that more actions will soon be filed.

Perhaps no single case will raise all of the issues that will be discussed in this article, but it is important that the Commission and the companies subject to its authority have a clearer under-

to Since parties subject to an FTC order were already subject to civil penalties under $\$$ $5(l)$ of the FTC Act, 15 U.S.C. $\$ 45(l)(1970$ \& Supp. V 1975), their treatment under $\$ 5(\mathrm{~m})$ is mystifying. The FTC can hardly be expected to invoke $\S 5(\mathrm{~m})$ against companies already under order, since $\$ 5(\mathrm{~m})$, unlike $\$ 5(l)$, requires a showing of "actual knowledge" by the defendant that its practices violate $\$ 5$. Moreover, once an order has become final, a defendant in an action under $\$ 5(l)$ may not relitigate the facts already determined adversely to him in the administrative proceeding. See FTC v. Morton Salt Co., 334 U.S. 37, 57 (1948). Under $\$ 5(\mathrm{~m})$, in contrast, it would still be open to the defendant to show that the FTC's findings were not supported by "substantial evidence." If the FTC's order has been affirmed on appeal, a challenge to the sufficiency of the FTC's evidence would probably be barred by res judicata. But if the defendant has foregone its right to appeal and has allowed the FTC's order to become final, there will have been no prior judicial determination of the substantiality of the evidence, and it is likely that the defendant could litigate the issue in the enforcement proceeding.

"FTC Announces Pilot Program (FTC Release, Jan. 5, 1976).

$\$ 2$ FTC News, Jan. 5, 1976 (about 100 notices were mailed); remarks of Caswell O. Hobbs before ABA Section of Antitrust Law, reprinted in 45 ANTITRUST L.J. 96, 114 (1976).

${ }^{13} 3$ Trade Reg. Rep. (CCH) If 21,306 (1977). 
standing of the scope and limitations of section $5(\mathrm{~m})$ than the published commentary has so far revealed. Section $5(\mathrm{~m})(1)(\mathrm{A})$, which imposes liability for rule violations, appears to raise few interpretative problems, and will be discussed only to the extent that its language and history help to explain the application of section $5(\mathrm{~m})(1)(B)$. Section $5(\mathrm{~m})(1)(B)$, which affects every commercial entity subject to the FTC's jurisdiction, ${ }^{44}$ has already been the subject of some debate and has evoked a variety of views concerning its workings, and even its constitutionality. ${ }^{45}$ These questions warrant further discussion before the courts are called upon to resolve them.

\section{The Requirement of a Prior FTC Determination}

\section{A. The New Role of Precedent}

Until the passage of the Magnuson-Moss Act, the FTC's consumer protection role had been subject to conflicting pressures. The Commission was expected to "discover and make explicit those unexpressed standards of fair dealing which the conscience of the community may progressively develop." 46 Yet the Commission, hampered by the lack of adequate remedial powers, devoted most of its attention to policing violations of existing law. The civil penalty provision of section $5(\mathrm{~m})$, together with the newly confirmed rulemaking power contained in section 18,47 may have the effect of shifting the primary enforcement of existing legal standards from the administrative arena to the courts, thereby encouraging the Commission to place greater emphasis on its law-creating role.

Section $5(\mathrm{~m})(1)(B)$ 's requirement of a prior FTC determination of illegality appears to serve two major purposes. First, the requirement protects defendants from retroactive law-making by the Commission. It would be unfair to permit the courts, at the Commission's behest, to impose penalties upon a defendant whose conduct had previously not been considered illegal..$^{48}$ So long as the FTC can

"The principal exclusions from the FTC's $\$ 5$ jurisdiction are banks, certain common carriers, and companies subject to the Packers and Stockyards Act. 15 U.S.C. $\$ 45(a)(6)$ (Supp. V 1975).

${ }^{15}$ See Abrams, Sections 205 and 206 of the Federal Trade Commisson Improvement Act, 44 Antitrust L.J. 523 (1975); Kintner and Smith, The Emergence of the Federal Trade Commission as a Formidable Consumer Protection Agency, 26 Mercer L. Rev. 651, 682 (1975); Comment, Civil Penalties and the Federal Trade Commission Improvements Act, 30 Sw. L. REv. 454 (1976).

" FTC v. Standard Educ. Soc'y, 86 F.2d 692, 696 (2d Cir. 1936) (L. Hand, J.), rev'd on other grounds, 302 U.S. 112 (1937).

${ }^{17}$ FTC Act \$ 18, 15 U.S.C. \$ 57a (Supp. V 1975).

s* Although the point was not specifically discussed with respect to civil penalties, much 
move only against conduct previously declared to be unlawful the Commission's new authority to create standards of conduct will work little hardship. The prior determination requirement serves a broad public purpose as well, by preserving to the Commission its traditional role of giving content to the broad statutory prohibition of "unfair or deceptive"practices. If the federal courts were authorized to determine in the first instance which practices are unfair or deceptive, the FTC's ability to provide for the "centralized and orderly development of precedent" would be impeded. ${ }^{49}$

The presence or absence of precedent for Commission interpretations of section 5 was not terribly significant prior to the passage of section $5(\mathrm{~m})(1)(B)$ since the Commission was empowered, in the context of an adjudicative proceeding, to enter cease and desist orders against practices that it determined were unfair or deceptive even though those practices had not previously been declared illegal..$^{50}$ For the first time, however, section 5 requires a careful evaluation of FTC precedents. Before deciding whether to impose civil penalties in any particular case, the court must first determine whether the FTC has previously held that the practice charged in the civil penalty complaint is unlawful. In reaching this decision the court will have to resolve a number of questions: when must the FTC's prior determination have been made; how and by whom must it have been made; and what was the scope of the prior determination?

\section{B. The Effect of Pre-1975 "Determinations"}

Before considering the possible form and scope of Commission caselaw determinations, it is important to face a preliminary question that is critical to the effective functioning of the statute. That question concerns the effect of Commission decisions made prior to the passage of the Magnuson-Moss Act. Section 5(m)(1)(A) clearly imposes civil liability for violations of "any" Commission trade regulation rule, whether adopted before or after January 4, 1975, the effective date of the Magnuson-Moss Act. However, it is unclear

the same point was made by Representative Joel Broyhill, the senior minority conferee from the House, in his discussion of the consumer redress provisions. 120 CoNG. REc. 31735 (1974).

19 See Holloway v. Bristol-Myers Corp., 485 F.2d 986, 998 (D.C. Cir. 1973). Although the threat to the "orderly development of precedent" is somewhat reduced when the FTC, rather than a private party, as in Holloway, calls upon the courts to interpret the FTC Act, the danger of the creation of inconsistent precedents among the district courts, or between a court and the Commission, remains.

:0 FTC v. Standard Educ. Soc'y, 86 F.2d 692 (2d Cir. 1936), rev'd on other grounds, 302 U.S. 112 (1937). 
from the language of section $5(\mathrm{~m})(1)(B)$ whether caselaw determinations of the Commission made prior to 1975 will likewise provide a basis for imposing civil penalties. Because subsection $(\mathrm{m})(1)(\mathrm{B})$ reads in the present tense ("If the Commission determines [that an act or practice is unlawful]") it has been suggested that caselaw principles developed by the Commission in the sixty years before the Magnuson-Moss Act cannot provide a basis for civil liability."1

This interpretation is not required by either the language or history of the statute. The language of subsection $(m)(1)(B)$ is not unambiguous. There is no indication that the draftsmen attached any special significance to the use of the present tense; indeed, the report of the Conference that inserted the language states that civil liability can be imposed for acts or practices that the Commission "has determined to be unfair or deceptive." 52

The history of section $5(\mathrm{~m})(1)(B)$ suggests that FTC caselaw determinations, whenever made, may provide the requisite predicate for civil liability. S. 3201, which contained the predecessor of the present civil penalty provision, listed fifteen categories of practices that would give rise to civil liability. This catalogue of "unfair consumer practices" was designed to codify clear violations that the Commission had identified and prohibited in caselaw decisions made during the previous fifty-five years. ${ }^{53}$ There was no question that these practices constituted a well-recognized set of violations, widely known to the business community. ${ }^{54}$ This type of explicit statutory codification was abandoned in subsequent versions of the proposed legislation in favor of more general language that imposed civil liability for engaging in "any act or practice which is unfair or deceptive to a consumer and is prohibited by [section 5(a) of the FTC Act]." "55 This change in the language, however, should not be interpreted as requiring a new determination that a particular practice violates section 5(a) if the practice had been declared unfair in a pre-1975 Commission decision. Even though the final version of section $5(\mathrm{~m})(1)(B)$ that emerged from the Conference Committee had been amended to require a prior Commission determination, this change should be viewed as an attempt to clarify which "unfair or deceptive" practices could be the basis for a civil penalty action

"Abrams, Sections 205 and 206 of the Federal Trade Commission Improvement Act, 44 ANTITRUST L.J. 523, 527 (1975).

52 S. REP. No. 93-1408, 93d Cong., 2d Sess. 40 (1974).

5 S. REP. No. 91-1124, 91st Cong., 2d Sess. 12-13 (1970).

st See, e.g., testimony of Assistant Attorney General McClaren and Professor Milton Handler, 1970 Senate Hearings, supra note 15, at 24-29, 297.

s S. 986, § 202, 92d Cong., 1st Sess. (1971); S. 356, § 202, 93d Cong., 1st Sess. (1973). 
under section $5(\mathrm{~m})(1)(B)$, not as a drastic cutback in the section's coverage. Had the Conference intended to limit the scope of civil liability to those practices that the Commission might determine in future proceedings to be unlawful, one would have expected some mention to have been made either in the Conference report or in the floor debates. On the contrary, the Conference report defined the requirement in terms of "acts or practices which the Commission has determined" were unlawful, and the sponsors of the bill discussed it in similar terms. ${ }^{56}$

To limit civil liability to violations of Commission caselaw principles established after the passage of the Magnuson-Moss Act would make little sense. Many obviously illegal practices would be allowed to flourish indefinitely if the Commission were required to reconfirm each of its prior determinations before it could impose liability upon a defendant under section $5(\mathrm{~m})(1)(B)$. Congress was undoubtedly aware of the vast body of Commission decisional law that had been developed over the past fifty years. ${ }^{57}$ Indeed, the very impetus for adding consumer redress, civil penalty, and injunctive power provisions was the concern that "hard core"-obviously illegal-activities would not be deterred by the mere threat of a cease and desist order. ${ }^{58}$

As an illustration of the absurdity of requiring the Commission to reconfirm each of its prior determinations, consider one such "hard core" practice-the sale of previously used products as if they were new. Virginia Knauer, Consumer Advisor to President Nixon, in her 1970 testimony on S. $3201,{ }^{59}$ singled out this practice as particularly egregious. As early as 1919, the Commission held unlawful the practice of selling retreaded tires as if they were new. ${ }^{60}$ This holding has been reiterated and applied to a multitude of other products, ${ }^{61}$ although no litigated order appears to have been issued by the Commission after 1974 . If Company $A$ were to begin to market retreaded tires at original equipment prices in January 1975, no significant interest would be served by permitting that company to

${ }^{56}$ For example, Senator Moss described the section as imposing penalties for "knowing violations of outstanding cease and desist orders." 120 CoNG. REc. 40712 (1974). Representative John Moss spoke in terms of "knowing violations of . . . orders [the FTC] has issued." 120 Cong. REc. 41406 (1974). The legislative history of the Magnuson-Moss Act was left intentionally ambiguous as to which Mr. Moss's name was incorporated into the Act's official title. See 117 CoNG. REC. 39865 (1971) (remarks of Senator Aiken).

${ }^{57}$ See S. Rep. No. 91-1124, 91st Cong., 2d Sess. 12-13 (1970).

${ }^{5 *}$ See S. REp. No. 93-151, 93d Cong., 1st Sess. 9-10 (1973).

591970 Senate Hearings, supra note 15 , at 26.

so William H. Batcheller, 2 F.T.C. 119 (1919).

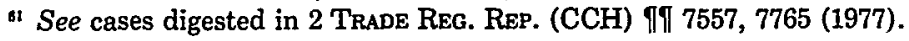


escape liability until the Commission happened to issue a final order reaffirming its determination of the illegality of this practice. Although the entry of a new order against Company $B$ might serve to remind $A$ that the practice was illegal, it is hard to see why the entry of the hundred previous orders would not provide sufficient notice. It is conceivable that certain of the old Commission decisions may no longer reflect the Commission's present interpretation of section 5 . There is, however, no reason to assume that principles that the Commission has developed and applied in a variety of factual settings and that the courts have consistently confirmed should be any less compelling than a Commission determination made in 1975 .

\section{Form of Prior Commission Proceeding}

1. "Final Order." Under section $5(\mathrm{~m})(1)(\mathrm{B})$ prior Commission determinations made in the context of formal adjudicative proceedings define the class of unfair or deceptive practices that may give rise to civil liability. The language of the section does not seem to require that these Commission determinations have been judicially affirmed; it simply requires that these determinations have resulted in a "final" order to cease and desist from the unlawful practice. ${ }^{62}$ Therefore, $A$ 's decision not to seek judicial review of a Commission determination should not preclude the Commission from seeking civil penalties against $B$ for engaging in the same practice. To satisfy the final order requirement, however, the Commission must have prohibited $A$ from engaging in the practice. Thus, the recent Commission announcements in the Pfizer $^{63}$ and National Dynamics $^{64}$ cases would not satisfy the final order requirement. In those cases, the Commission announced that the making of an "affirmative product claim" without prior reasonable substantiation is an unfair and deceptive practice. However, since the "reasonable basis" charges were dismissed in both cases and cease and desist orders were not issued in connection with the charges, the Commission's pronouncements of law cannot serve as predicates for civil liability.

2. Consent Orders. Just as cases such as Pfizer and National Dynamics will not provide a predicate for a civil penalty action

42 Under $\$ 5(\mathrm{~g})$ of the FTC Act, 15 U.S.C. $\$ 45(\mathrm{~g})(1970)$, a cease and desist order becomes final if no petition for review has been filed within 60 days after service of the order.

ss Pfizer, Inc., 81 F.T.C. 23 (1972).

4 National Dynamics Corp., 82 F.T.C. 488 (1973), aff'd in part, remanded in part, 492 F.2d 1333 (2d Cir.), cert. denied, 419 U.S. 993 (1974). 
under section $5(\mathrm{~m})(1)(B)$, neither will the numerous consent orders that the Commission has issued in the wake of those cases. ${ }^{65} \mathrm{Con}$ sent orders are final orders within the meaning of section $5(\mathrm{~g})$ of the FTC Act, ${ }^{66}$ but they do not generally embody the type of "determination" required by section $5(\mathrm{~m})(1)(\mathrm{B})$.

Ordinarily, the only findings made by the FTC in conjunction with a consent order concern the existence of a "public interest" in the proceeding and the questions of subject matter and personal jurisdiction. ${ }^{67}$ As for the practices charged in the complaint that is issued along with the order, the Commission need only have "reason to believe" that the charged practices violate section 5 . The Commission does not conclusively determine that the practices are unfair or deceptive. Therefore, a consent order cannot properly be viewed as reflecting the FTC's acceptance of the validity of either the factual or the legal theories asserted in the complaint. ${ }^{69}$ Indeed, the Commission itself attaches scant precedential value to prior consent orders even in subsequent administrative proceedings. ${ }^{70}$

Whether a form of Commission action satisfies the prior determination requirement should be resolved in light of the purposes of the requirement. In the absence of a clear prior determination, firms subject to FTC jurisdiction would not be afforded adequate notice of the law's proscriptions. Moreover, a district court trying a $5(\mathrm{~m})(1)(B)$ enforcement proceeding predicated on an ambiguous consent order would be compelled to construct legal principles that

\footnotetext{
${ }^{65}$ E.g., Wasem's, Inc., 84 F.T.C. 209 (1974); Volvo, Inc., 82 F.T.C. 1851 (1973); Sugar Information, Inc., 81 F.T.C. 711 (1972).

${ }_{66}$ United States v. Vitasafe Corp., 212 F. Supp. 397 (S.D.N.Y. 1962), aff'd per curiam, 352 F.2d 62 (2d Cir. 1965).

${ }^{67}$ Although the Commission's rules require that these "jurisdictional facts" be admitted, they permit the consent agreement "in appropriate circumstances" to contain a statement that the respondent does not admit to a violation of the law. 16 C.F.R. $\$ 2.32$ (1977). Section 5(b) of the Act requires the FTC to make factual findings if it is "of the opinion that the... act or practice in question is prohibited," 15 U.S.C. $\$ 45$ (b) (Supp. V 1975), but a consent order arguably does not require that the FTC form such an opinion. In any event, 16 C.F.R. $\$ 2.32$ requires a respondent entering into a consent agreement to waive its right to factual and legal findings. The validity of this section was upheld in Ford Motor Co. v. FTC, 547 F.2d 934 (6th Cir. 1976), cert. denied, 97 S. Ct. 2176 (1977).

6* FTC Act § 5(b), 15 U.S.C. \$ 45(b) (Supp. V 1975).

69 United States v. ITT Continental Baking Co., 420 U.S. 223, 236 (1975) (citing United States v. Armour \& Co., 402 U.S. 673, 681-82 (1971)). But cf. FTC v. Mandel Bros., 359 U.S. 385,391 (1959) (FTC interpretation of statute entitled to "great weight," even though made in context of consent order proceeding).

${ }^{70}$ See Giant Food, Inc., 61 F.T.C. 326, 355 (1962), aff'd, 322 F.2d 977 (D.C. Cir. 1963). It is the view of at least two FTC Commissioners that "[i]n a consent somebody can agree to jump off [the] Brooklyn Bridge and that is all right . . . " Fedders Corp., Dkt. No. 8932, Transcript of Argument (November 18, 1974).
} 
support that decree-in derogation of the Commission's primrry responsibility to articulate section 5 law. Any notice objections or inappropriate forum problems are avoided, however, if the consent order is accompanied by reasonably intelligible findings of fact and conclusions of law. The Commission could decide to adopt factual and legal findings in conjunction with its consent orders, and to treat these findings as a "determination" of the Commission for purposes of section $5(\mathrm{~m})$. Nothing in the FTC Act precludes the Commission from accompanying its consent orders with formal findings, and, indeed, it was the Commission's practice to do so until the early 1950's. ${ }^{71}$ Even though such findings are no longer required, the FTC's consent order rules provide a respondent with the option of admitting "the proposed findings of fact and conclusions of law submitted by the Commission's staff." 72 Such consent orders could be viewed as equivalent to adjudicated orders based upon stipulated findings, ${ }^{73}$ and might therefore satisfy the "determination" requirement of section $5(\mathrm{~m})(1)(B)$.

3. Uncontested Decisions. A number of precedents that the FTC may invoke in civil penalty proceedings were developed in litigated proceedings in which the respondent chose not to challenge the validity of the legal principle applied to its conduct. For example, most of the cases concerning the failure to disclose the previous use of advertised goods that the Commission has cited in letters sent to companies under its pilot enforcement program ${ }^{74}$ were decided upon admissions by the respondent or upon stipulated facts. Similarly, in Fedders Corp. ${ }^{75}$ a litigated case in which the Commission issued a final order prohibiting the making of claims without a "reasonable basis," the respondent admitted all relevant facts, but argued unsuccessfully that its transgressions were insubstantial and had, in any event, been discontinued..$^{76}$

1 Until 1951, the FTC's rules contained no provision for consent orders. Nevertheless, consent orders were obtained through negotiated stipulations that were submitted to the Commission for approval. The procedure was reconstructed for the benefit of posterity in National Biscuit Co., 79 F.T.C. 264, 273-75 (1971), aff'd sub nom. Nabisco, Inc. v. FTC, 459 F.2d 1023 (5th Cir. 1972) (per curiam).

3216 C.F.R. \& 2.32 (1977).

is Cf. United States v. International Bldg. Co., 345 U.S. 502, 506 (1953) (suggesting that consent decree may have collateral estoppel effect if based upon findings).

"See text at note $41-43$ supra.

${ }^{25}$ Fedders Corp., 85 F.T.C. 38 (1975), aff'd, 525 F.2d 1398 (2d Cir.), cert. denied, 429 U.S. 818 (1976).

7 Although the company's answer denied those paragraphs of the complaint that alleged that its conduct was unlawful, id. at 44, it appears to have abandoned its position at trial, $i d$. at 55, and did not raise the issue before the Commission in its appeal. Id. at 71 . 
Despite the absence of a live dispute between the Commission and the respondents on the legal issues in these cases, the decisions rendered should satisfy the statutory requirement of a prior Commission determination. Unlike the ordinary consent order, the filing of an admission answer or the stipulation of facts does not relieve the administrative law judge of his obligation under the Commission's rules to make findings of fact and conclusions of law, which the Commission may later "adopt, modify or set aside." "77 Nor does it relieve the FTC of its statutory obligation, under section $5(\mathrm{~b})$ of the FTC Act, to make "a report in writing in which it shall state its findings as to the facts" violated. While the findings of the administrative law judge may frequently be accepted with little scrutiny, there have been occasions on which the Commission has exercised its authority to reject these findings. Even though these findings may have been rendered upon a stipulation, the Commission may dismiss the findings and portions of an otherwise uncontested complaint..$^{79}$

4. Unappealed Initial Decisions. In some cases, the initial decision rendered by an administrative law judge will result in the issuance of a final order if neither party appeals the decision to the Commission. In its initial enforcement effort under section $5(\mathrm{~m})(1)(B)$, the Commission indicated that it may rely on some of these unappealed decisions of administrative law judges. ${ }^{80}$ Although one Commissioner dissented, ${ }^{81}$ the majority of the Commission correctly concluded that unappealed initial decisions satisfy the "determination" requirement of section $5(\mathrm{~m})(1)(B) .{ }^{82}$ Under both the Administrative Procedure Act ${ }^{83}$ and the FTC's own rules, ${ }^{84}$ an unappealed initial decision becomes the Commission's decision unless the Commission sua sponte places the matter on its appeal docket. Formally at least, determinations made in unappealed ini-

$" 16$ C.F.R. $\$ \S 3.51(\mathrm{~b}), 3.54(\mathrm{~b})(1977)$.

${ }^{78} 15$ U.S.C. $\$ 45(\mathrm{~b})$ (Supp. V 1975).

7 See, e.g., Paul J. Lighton, 60 F.T.C. 821, 828 (1962).

*o Among the unappealed initial decisions served by the FTC under its pilot program were Sun Oil Co., 84 F.T.C. 247 (1974) (deceptive demonstration); Seekonk Freezer Meats, Inc., 82 F.T.C. 1025 (1973) (bait and switch); and Metropolitan Golf Ball, Inc., 66 F.T.C. 378 (1964) (failure to disclose used nature of product).

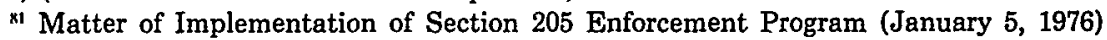
(Nye, Comm'r, dissenting).

$1 d$. at 3.

${ }^{*}$ Section 8(a) of the Act, 5 U.S.C. $\$ 557(b)$ (1970), provides, "When the presiding employee makes an initial decision, that decision then becomes the decision of the agency without further proceedings unless there is an appeal to, or review on motion of, the agency within the time provided by rule."

\$ 16 C.F.R. $§ 3.51$ (a) (1977). 
tial decisions are as much determinations of the Commission as are decisions made after full briefing and argument. Although the failure to appeal from an initial decision will foreclose the respondent from judicial review, section $5(\mathrm{~m})$ does not require as a predicate for civil liability that otherwise final FTC orders also have been judicially reviewed.

In his dissent from the Commission's conclusion that it could rely on initial decisions, Commissioner Nye asserted that such decisions are not accorded "the precedential weight of stare decisis." 85 Initial decisions are, of course, no more "binding" upon the FTC than are decisions with opinions written by the Commission itself, ${ }^{86}$ and the Commission, may, if it wishes, accord less weight to decisions that it has not reviewed. It is another matter altogether, however, to conclude that the Commission does not "take account of unappealed initial decisions in making its own adjudicative determinations." 87 Even if the Commission has ever taken such a position, ${ }^{88}$ its validity is doubtful.

Although no case concerning the precedential effect of an unappealed initial decision appears to have arisen under the FTC Act, a recent decision under the Occupational Safety and Health Act of $1970,{ }^{89}$ which has similar appeal procedures, appears applicable to the FTC as well. Under that Act, civil penalty actions for "serious" violations are heard initially by an administrative law judge of the Occupational Safety and Health Review Commission (OSHRC)..$^{90}$ "Reports" of the law judge become final orders of OSHRC unless a Commission member directs that the matter be reviewed by the full

*s Matter of Implementation of Section 205 Enforcement Program 5 (January 5, 1976) (Nye, Comm'r, dissenting).

* See Montgomery Ward \& Co. v. FTC, 379 F.2d 666, 671 (7th Cir. 1967); Giant Food, Inc. v. FTC, 322 F.2d 977, 983 (D.C. Cir. 1963) (citing FCC v. WOKO, Inc., 329 U.S. 223, 228 (1946)).

"7 Matter of Implementation of Section 205 Enforcement Program 5-6 (January 5, 1976) (Nye, Comm'r, dissenting).

* Commissioner Nye's dissent referred to a change in the boilerplate recitation used by the Commission in issuing orders where no appeal has been taken from the initial decision. Before 1974 unappealed initial decisions were said to have been "adopted and issued as the decision of the Commission," while initial decisions in later years are typically described as having "become effective." Compare Seekonk Freezer Meats, Inc., 82 F.T.C. 1025, 1060 (1973), with Avalon Industries, Inc., 83 F.T.C. 1728, 1756 (1974). The change in formula was unaccompanied by any change in Rule 3.51 or by any public discussion at all. In view of the rule and section 557 of the APA, the change at best should be interpreted as only an indication that the FTC will accord somewhat less precedential weight to unappealed initial decisions than it does to decisions rendered after plenary review.

s) 29 U.S.C. $\$ \S 651-678$ (1970).

× 29 U.S.C. $\$ \S 661(\mathrm{i}), 666(\mathrm{~b})(1970) ; 29$ C.F.R. $\S 2200.66$ (1976). 
OSHRC within thirty days after entry of the initial decision..$^{91}$ In Brennan v. Gilles \& Cotting, Inc., ${ }^{92}$ the Secretary of Labor appealed an OSHRC reversal of a civil penalty assessment against a contractor for having a defective scaffold. The Commission had determined that there was no proof that any of the defendant's payroll employees actually had been exposed to the "zone of danger" created by the defect. The Court of Appeals remanded to OSHRC for reconsideration in light of two unappealed determinations of administrative law judges that it was sufficient for liability that a defendant's employees had access to the defective equipment, even though no employee had used the defective equipment. While emphasizing that OSHRC was no more "bound" by these prior decisions than it would have been had OSHRC rendered the decisions, the court held that the Commisson was obliged to give a reasoned explanation for its departure from precedent..$^{93}$

As Gilles \& Cotting suggests, the Commission may not ignore its own decisions merely because it has declined to exercise its powers of plenary review. Even though a respondent chooses not to seek Commission review of an issue, the Commission is nevertheless obligated to maintain a coherent body of trade regulation law, in order to provide a semblance of guidance to businesses. Traditionally, when important legal issues have been improperly decided by the law judge, the Commission has not hesitated on its own motion to review and reject, or at least substantially modify, the findings and orders of the law judge. ${ }^{84}$

Commissioner Nye's suspicion that some unappealed initial decisions contain misstatements of law ${ }^{95}$ is undoubtedly warranted, but the same observation could be made of FTC decisions generally, many of which have remained on the books for decades without reexamination. The suggestion that non-parties therefore may be

91 29 U.S.C. $\$ 661(\mathrm{i})(1970)$.

${ }^{92} 504$ F.2d 1255 (4th Cir. 1974).

${ }^{93}$ Id. at 1264-66. Despite Gilles \& Cotting, OSHRC has recently stated that unreviewed decisions of its law judges do not "necessarily express the views of the Commissioners or ... Commission policy." Leone Constr. Co., 3 O.S.H.C. 1979, 1981 (1976). But see id. at 1983-84 (Morin, Comm'r, dissenting). Like Commissioner Nye, the OSHRC seems to confuse a strict rule of stare decisis with the concept of precedent. Although the court in Gilles \& Cotting did not direct OSHRC to accord unreviewed decisions "any particular precedential value," 3 O.S.H.C. at 1981 (emphasis added), it required OSHRC to come to grips with these decisions whether it ultimately chose to accept or reject them.

9s See, e.g., Wilbanks Carpet Specialists, Inc., 84 F.T.C. 510 (1974) (modifying unappealed order, sua sponte); Paul J. Lighton, 60 F.T.C. 821, 828 (1962).

${ }_{93}$ Matter of Implementation of Section 205 Enforcement Program 4 (January 5, 1976) (Nye, Comm'r, dissenting). 
"bound" by such incorrect and unauthoritative decisions, ${ }^{96}$ however, is incorrect. The Commission is not likely to commit substantial resources to recover penalties for the violation of caselaw principles that it now believes are erroneous. Moreover, even if the Commission proceeds in such a bad faith manner, defendants will not be "bound" by these determinations, since, as discussed below, the validity of prior determinations will ultimately be for the courts to decide..$^{97}$

\section{Finding the Commission Determination}

The FTC caselaw "determinations" that provide a basis for imposing civil liability under section $5(\mathrm{~m})(1)(B)$ are scattered throughout the eighty-seven published volumes of reported FTC decisions. Unfortunately, it will not always be a simple task to find these determinations or to relate them to the practices for which a civil penalty defendant is charged. Even a firm against whom a cease and desist order has been issued cannot always identify with any precision the practice that the Commission deemed violative of the Act. In section $5(\mathrm{~m})(1)(B)$ proceedings, the tasks will be far more difficult because the defendant typically will be a stranger to the original cease and desist proceeding. His conduct will be evaluated not against the terms of a Commission order concerning his particular activities, but instead against a Commission decision underlying an order issued in another defendant's case.

Although there is some suggestion in both the language and the legislative history of section $5(\mathrm{~m})$ that violations of the terms of FTC orders will suffice to create liability ${ }^{98}$ such a construction is almost certainly too broad. Section 5(b) of the FTC Act requires the Commission to issue an order to cease and desist from "such act or practice" found to violate section 5(a)(1). But the typical FTC order goes well beyond defining the practices that the Commission has identified as unlawful in its decision. From its inception the Com-

"Id.

"See text and notes at notes 172-193 infra.

9x The language of $\S 5(\mathrm{~m})$ itself is somewhat inconsistent. Section $5(\mathrm{~m})(2)$ refers to a "cease and desist order establishing that the act or practice is unfair or deceptive." On the other hand, $\S 5(\mathrm{~m})(1)(\mathrm{C})$ provides for penalties for a "continuing failure to comply with a rule or with subsection $5(a)(1)$." Section $5(a)(1)$ does not refer to cease and desist orders, but merely states that "[u]nfair or deceptive acts or practices . . . are declared unlawful." This inconsistency carried over to the floor discussions. Although the floor managers in both houses referred to the imposition of penalties for violations of "cease and desist orders," see 120 Cong. Rec. 40712 (1974) (remarks of Senator Moss), 120 Cong. Rec. 41406 (1974) (remarks of Rep. Moss), Senator Magnuson, the Act's co-author, talked in terms of penalties for "violations of the Federal Trade Commission Act." 120 CoNG. REc. 40713 (1974). 
mission has routinely included in its orders a variety of reporting and recordkeeping requirements designed not to prohibit unlawful conduct, but rather to facilitate the Commission's task of monitoring future compliance. ${ }^{99}$ Apart from these ancillary provisions, the Commission frequently prohibits conduct that is not unlawful in itself if the Commission believes that such conduct might enable a former lawbreaker to accomplish unlawful ends. Within certain first amendment constraints, ${ }^{100}$ the courts have generally approved FTC prohibitions of a variety of otherwise lawful activities. ${ }^{101}$ For example, in Arthur Murray Studio of Washington, Inc. v. FTC, ${ }^{102}$ the court affirmed a Commission order imposing a price ceiling on future dance instruction contracts. Although the Commission had declined to hold that higher-priced contracts were per se unfair, ${ }^{103}$ the court agreed that the imposition of a price ceiling was an appropriate means of rendering future deception or coercion less attractive to the respondent. ${ }^{104}$ Clearly, the Arthur Murray order would not justify a Commission decision to seek civil penalties from a third party merely because it had entered into contracts containing a price higher than that permitted in the Arthur Murray order.

A more difficult issue is presented by Commission orders that, while purporting to prohibit only unlawful acts, in fact reach well beyond the specific practices enumerated by the Commission in its administrative proceeding. Some of these orders are framed in terms that are almost as broad as section 5 itself. ${ }^{105}$ Although these orders have not always survived judicial review, ${ }^{106}$ sufficiently blatant con-

"See, e.g., American Aluminum Corp., 84 F.T.C. 21, 55-56 (1974), aff'd mem., 522 F.2d 1278 (5th Cir.), cert. denied, 426 U.S. 906 (1976). From its earliest days, the FTC has incorporated into its orders a requirement that the addressee provide compliance reports. See G. Henderson, The Federal Trade Commission 77 (1924).

${ }^{100}$ See, e.g., Beneficial Corp. v. FTC, 542 F.2d 611, 618-20 (3d Cir. 1976), cert. denied, 97 S. Ct. 1679 (1977).

${ }^{101}$ E.g., FTC v. National Lead Co., 352 U.S. 419, 430 (1957); Arthur Murray Studio of Washington, Inc. v. FTC, 458 F.2d 622 (5th Cir. 1972).

102458 F.2d 622 (5th Cir. 1972).

${ }^{103}$ Arthur Murray Studio of Washington, Inc., 78 F.T.C. 401, 438 (1971).

104 458 F.2d at 626. See Tashof v. FTC, 437 F.2d 707, 713 (D.C. Cir." 1970); S \& S Pharmaceutical Co. v. FTC, 408 F.2d 487 (5th Cir. 1969); cf. All-State Indus. of N.C., Inc. v. FTC, 423 F.2d 423, 425 (4th Cir.), cert. denied, 400 U.S. 828 (1970) (notice that instrument may be negotiated to third party affirmed both on basis of FTC finding that non-disclosure would be deceptive and because notice would be a "needed public precaution" against future deceptions).

10s The FTC's tendency to issue sweeping orders is nothing new. For example, in Boston Piano \& Music Co., 3 F.T.C. 168, 175 (1920), the order prohibited the respondent from "misleading ... purchasers ... by any ... communication containing any false, misleading or deceptive statement or misrepresentation." Nor is criticism of such orders anything new. See G. Henderson, The Federal Trade Commission $72-77$ (1924).

${ }_{106}$ See, e.g., American Home Prods. Corp. v. FTC, 402 F.2d 232, 237 (6th Cir. 1968). 
duct may induce a court to sustain such a broad Commission order as reasonably necessary to "fence in" a particular respondent. For example, in Consumer Products of America, Inc. v. FTC, ${ }^{107}$ the court approved an order that prohibited the respondent from "using in any manner a sales plan, scheme or device wherein false, misleading or deceptive statements or representations are made in order to obtain leads or prospects for the sale of merchandise or services." 108 It is difficult to imagine an order broader in its sweep. As the court itself recognized, the order essentially bound the company to "tell the truth" 109 in the future. Even though it is surely a section 5 violation to fail to tell the truth, the acceptance of such an openended admonition as a "determination" that a failure to tell the truth is an unfair or deceptive practice would render the determination requirement nugatory. If Congress believed that the sweeping statutory prohibition of "unfair or deceptive" practices was inadequate to provide guidance to companies seeking to avoid penalties, it could hardly have intended that the prohibition be replaced by one equally as broad. It would be more appropriate, therefore, to view the FTC's determination in cases like Consumer Products as limited to the type of bait-and-switch and pricing tactics that were the subject of the complaint. ${ }^{110}$

Since the terms of Commission orders do not often identify the practices that the Commission has determined to be unlawful, the Commission's determination must be gleaned from the formal findings and conclusions and from the "statement of reasons or basis" which the Commission's rules require it to adopt in each decided case. ${ }^{11}$ Unfortunately, it is not always easy to determine from a reported Commission decision just what practice was held unlawful. One difficulty is that for most of its history the FTC did not issue opinions to accompany its decisions. Until the early 1950's the Commission, with very few exceptions, made no attempt to give reasons

107400 F.2d 930 (3d Cir. 1968).

${ }^{108}$ Id. at 933.

102 Id. at 934 .

110 This is not to suggest that the court in the Consumer Products case erred in affirming the FTC's order. Both the Commission and the court may properly have viewed the respondent as a hardened offender likely to lapse unless kept on a very tight leash. Cf. American Home Prods. Corp. v. FTC, 402 F.2d 232, 237 (6th Cir. 1968) (blanket prohibition against future false advertising for any drug inappropriate when company is not a "habitual offender"). In constrast, $\$ 5(\mathrm{~m})$ imposes liability on first offenders and does not provide potential defendants with the guidance made available to those already under order through the FTC's compliance procedures.

"I 16 C.F.R. § 3.54(b) (1977). 
for its decisions. ${ }^{12}$ The typical Commission decision consisted solely of a series of boilerplate "findings of fact" which typically did no more than restate the equally standardized language of the complaint. References to prior Commission or judicial decisions construing the Act were rare in deceptive practices cases, as was any "reasoned discussion of the principles of law involved."113 A full examination of the shortcomings of these old FTC decisions is beyond the scope of this article, but a few examples, drawn from substantive principles of law mentioned previously in the article, will help illustrate some of the pitfalls involved in trying to identify those practices that the Commission has already determined to be unfair.

In some instances it is not possible to pinpoint the theory of violation adopted by the Commission. For example, in the early case of Health Violet Products, ${ }^{114}$ the respondent marketed a machine that was claimed to cure eighty-four different diseases ranging from abscesses to writer's cramp, including cancer in its "mild form." 115 The Commission concluded that these claims were deceptive and prohibited future "cure" claims for the machine. The basis for the Commission's conclusion is unclear. Although the Commission found that the machine had "no curative effect or value whatsoever,"116 it also found that the respondent had failed to conduct any tests or experiments to determine the asserted curative value of the machine. As a result, the respondent knew "nothing about" the properties of the machine, and the list of diseases for which the device was asserted to be beneficial had merely been copied from a circular that the respondent had found.17

Was the Commission's decision in the Health Violet case a "determination" that the practice of making unsubstantiated product claims is unfair or deceptive? Although one commentator appears to have reached this conclusion, at least with respect to "improbable" claims, ${ }^{118}$ it is impossible to tell from the Commission's decision itself. It could be contended that the Commission

112 Howrey, Federal Trade Commission Decisions, 4 ABA AnTitrust Section 133, 140-41 (1954).

13 Attorney General's Comm'n on Administrative Procedure, Final Report of Attorney General's Committee on Administrative Procedure, S. Doc. No. 8, 77th Cong., 1st Sess. 443 (1941).

iII 13 F.T.C. 134 (1929).

$115 \mathrm{Id}$. at 138.

I16 Id. at 139 .

117 Id. at 138.

118 G. Alexander, Honesty and Competition 99 (1967). 
found the respondent's claim to be unfair because it was both false and unsubstantiated. On the other hand, it is equally arguable that the Commission's findings on the lack of substantiation were included either to express the Commission's view on the weight of the evidence presented on the falsity charge or to express the Commission's view that the respondent did not act in good faith. The Commission's only real "determination" may have been that the specific advertising claims for the product were false. ${ }^{119}$

Fortunately, the Commission need not rely on the Health Violet case as a precedent for imposing civil liability for a failure to have a "reasonable basis," 120 since final orders were entered in 1976 in two litigated cases that explicitly adopted the "reasonable basis" principle announced in the Pfizer case.121 The Commission, however, has not had the occasion to reconsider the issues presented in many of its older cases. There is one line of early cases in which the Commission prohibited companies from marketing goods under the name of a separately-incorporated subsidiary, without disclosing the parent's name. ${ }^{122}$ It is unclear whether these decisions were based on a finding of deception or on some notion of competitive unfairness. ${ }^{123}$ Since the Commission has not had the opportunity to reconsider the rationale, scope, or continued vitality of these decisions, ${ }^{124}$ a com-

11 Although the complaint is reproduced only in synopsis form in the official report, it appears that only falsity was charged. See 13 F.T.C. at 134.

120 The Commission did not cite the Health Violet case in its Pfizer opinion and indeed appears never to have cited it in any subsequent opinion.

${ }^{123}$ Fedders Corp., 85 F.T.C. 38, 58 (1975), aff'd, 529 F.2d 1398 (2d Cir.), cert. denied, 429 U.S. 818 (1976); Crown Cent. Petroleum Corp., 84 F.T.C. 1493, 1548 (1974), aff'd mem., 530 F.2d 1093 (D.C. Cir. 1976).

:22 E.g., Armour \& Co. 1 F.T.C. 430 (1919); A.A. Berry Seed Co., 2 F.T.C. 427 (1920); St. Louis Lightning Rod Co., 3 F.T.C. 327 (1921).

12 Compare G. Henderson, The Federal Trade Commission 226 (1924) (emphasizing "deceptive element" of practice) with Handler, Unfair Competition and the Federal Trade Commission, 8 GEo. WASH. L. REv. 399, 414 (1939) ("monopolistic character" of practice).

Since liability under $\S 5(\mathrm{~m})$ may be imposed only for practices that are "unfair or deceptive" to the consumer, and not for "unfair methods of competition," the FTC's characterization of the practice is critical. FTC v. Sperry \& Hutchison Co., 405 U.S. 233, 246-50 (1972) (remanding for FTC determination whether practice is unfair to consumers or to competition). The "unfair or deceptive" language was added to $\S 5$ by the Wheeler-Lea Act of 1938, ch. 49, § 3, 52 Stat. 114 (1938), which nullified the Supreme Court's holding in FTC v. Raladam Co., 283 U.S. 643 (1931). Raladam held that deceptive practices could not be prohibited unless they were shown to have an adverse effect upon competition. Although the FTC's pre-1938 decisions do not therefore contain specific findings that the practice in question was "unfair or deceptive," decisions that clearly indicate that the method of competition was unfair because it tended to deceive consumers should satisfy the "determination" requirement of $\S 5(\mathrm{~m})(1)(\mathrm{B})$.

121 In the most recent "bogus independent" case, L.G. Balfour Co., 74 F.T.C. 345, 50405 (1968), aff'd, 442 F.2d 1 (7th Cir. 1971), the Commission held that Balfour's covert acquisi- 
pany that today markets goods under the name of one of its subsidiaries cannot predict whether it is risking civil penalties, or whether these old "bogus independent" cases simply stand for some narrower principle. ${ }^{125}$

Even when the FTC has repeatedly dealt with an issue, questions may arise about the applicability of a particular caselaw determination to the practices engaged in by a potential defendant. If the FTC, for example, has prohibited an advertising claim made in connection with the marketing of a given product, may penalties be imposed upon a defendant who makes the same type of claim about a different product? Some FTC caselaw principles are obviously product-specific. The prohibition against making unqualified safety claims for tires, for example, clearly derives from the Commission's findings about the specific characteristics of tires and their users. ${ }^{126}$ The Commission could not, on the authority of the tire precedent, impose penalties on a seller of products other than tires. In contrast, the Commission's prohibition of the use of undisclosed "mockups" was explicitly premised on a finding that the practice in general was deceptive; the principle is not limited to the product-shaving cream - that was the subject of the Commission's complaint. ${ }^{127}$

The Commission, however, has not always taken the trouble to identify precisely the practice it has determined to be unlawful. There are perhaps a hundred litigated cases, involving dozens of products, in which the Commission has prohibited the failure to

tion and operation of a competitor was an unfair method of competition because it served "to maintain and increase [Balfour's] monopolistic position." None of the earlier cases was cited in the Commisson's opinion. Although the FTC has recently rejected a proposal to institute a trade regulation rule proceeding concerning the disclosure of corporate ownership of consumer product marketing subsidiaries, the rejection appears to have been based primarily on the Commission's unwillingness to commit resources to the area. The Commission did, however, suggest that the identity of the parent might frequently be immaterial to consumers. Antitrust \& Trade Reg. Rep. (BNA) No.771, A-14 (July 6, 1976).

12 When a new subsidiary is created in order to lure customers who had previously purchased shoddy goods from the parent, one could reasonably conclude that the practice had previously been determined to be deceptive. See A.A. Berry Seed Co., 2 F.T.C. 427 (1920). It is not clear, however, whether the FTC has generally held the creation of subsidiaries "to reach customers who are considered hostile to the parent concern" to be unfair. G. HENDERson, The Federal Trade Commission 226 (1924). Although the Armour case cited in note 122 supra arguably stands for such a broad proposition, the Commission's cryptic findings in that case make it impossible to tell whether the deception, if any, was occasioned by the farmers' antipathy toward Armour or their preference for its subsidiary, which had falsely held itself out as a "co-operative." Cf. Educators' Ass'n, Inc. v. FTC, 108 F.2d 470 (2d Cir. 1939) (implied representation that profit-making entity is non-profit violates $\S 5$ ).

${ }^{126}$ See Firestone Tire \& Rubber Co., 81 F.T.C. 398 (1972), aff'd, 481 F.2d 246 (6th Cir. 1973), cert. denied, 414 U.S. 1112 (1974).

${ }_{127}$ Colgate-Palmolive Co., 62 F.T.C. 1269, 1276, remanded, 326 F.2d 517 (1st Cir. 1963), rev'd, 380 U.S. 374 (1965). 
disclose that apparently new products have been previously used, but it is difficult to find a case in which the Commission has stated as a general principle that the failure to disclose the fact of prior use is deceptive. Instead, its findings have been limited to the particular product involved in each case. Clearly, a tire dealer who sells retreads without disclosing the fact of prior usage is risking civil penalties, ${ }^{128}$ as is a seller of rewashed golfballs. ${ }^{129}$ The seller of used bicycles also might be risking civil penalties even though no FTC caselaw determination has ever specifically involved used bicycles. In the first place, the Commission has in at least one case issued an order that prohibited the sale of any used product without an appropriate disclosure of prior use..$^{130}$ The entry of such a broad order applicable to all products strongly suggests that the Commission had determined the practice to be deceptive without regard to the particular product involved. ${ }^{131}$ Second, even in the absence of an allproducts order, it would still be open to the FTC to argue that the practice was sufficiently similar to those previously held illegal to warrant the imposition of penalties. Section $5(\mathrm{~m})(1)(\mathrm{B})$ speaks in terms of "such practice(s)" as the Commission has previously determined to be unlawful-language identical to that of section 5(b) of the Act, which has consistently been held to empower the Commission to prohibit "like and related" practices. ${ }^{132}$ Under section $5(\mathrm{~m})(1)(\mathrm{B})$, the courts and not the Commission will have to determine in the first instance whether a given practice was "like and related" to that previously found to be unlawful. Although the courts have previously had little trouble making similar determinations, ${ }^{133}$ the Commission should articulate its theories of illegality more clearly than it has in the past.

12x See text at note 60 supra.

12 See Metropolitan Golf Ball, Inc., 66 F.T.C. 378 (1964).

130 Joseph A. Winkler \& Co., 46 F.T.C. 107, 114 (1949).

131 Unlike the cases discussed in notes 103-105 supra and accompanying text, there is no basis for concluding that the order was designed to prohibit otherwise lawful conduct. Even though a fertile imagination could conjure up instances in which a "used" product may be more desirable than a new one (e.g., when the "used" product is a valuable antique), the likelihood of this occurring is sufficiently small to justify a blanket prohibition.

132 FTC v. Mandel Bros., Inc., 359 U.S. 385, 393 (1959). See Benrus Watch Co. v. FTC, 352 F.2d 313, 324 (8th Cir. 1965), cert. denied, 384 U.S. 939 (1966); Niresk Industries, Inc. v. FTC, 278 F.2d 337, 343 (7th Cir.), cert. denied, 364 U.S. 883 (1960).

137 For example, in Consolidated Book Publishers, Inc. v. FTC, 53 F.2d 942, 945 (7th Cir. 1931), cert. denied, 286 U.S. 553 (1932), the court had no trouble concluding that the sale of a 10-year old encyclopedia under a new name was equivalent to selling an old movie under a new title, a practice held unlawful in Fox Film Corp. v. FTC, 296 F. 353 (2d Cir. 1924). 


\section{III. "Actual KNOWLEDGE"}

Under section $5(l)$ of the FTC Act, a party who is subject to a cease and desist order may be assessed penalties of up to $\$ 10,000$ per day for each violation of the order committed after the order has become final. The main issue to be resolved by the district court in a proceeding under section $5(l)$ is whether the defendant has engaged in practices that violate the terms of the order. ${ }^{134}$ The court is not concerned with whether the defendant's practices are themselves unfair or deceptive since this issue has already been adjudicated in the administrative proceeding against the defendant. Moreover, although the defendant's good faith may be considered as a factor bearing on the amount of the penalty to be assessed, courts have consistently held that a defendant's ignorance that his conduct violates the order is no defense to liability. ${ }^{135}$

In contrast, civil penalties under section $5(\mathrm{~m})(1)(\mathrm{B})$ may be assessed against a defendant not previously subject to a cease and desist order only if the Commission can show that the defendant had "actual knowledge that such practice is unfair or deceptive and unlawful under [section 5(a)(1)]." ${ }^{136}$ Two questions are raised by this language. First, of what must the defendant have knowledge before he is subject to civil penalties? Second, what mental states will satisfy the "actual knowledge" requirement? Like so many other provisions of section $5(\mathrm{~m})(1)(\mathrm{B})$, the "actual knowledge" requirement is subject to conflicting interpretations.

A literal reading of the statute seems to suggest that the defendant must be shown to have had knowledge (1) that its practices were either "unfair" or "deceptive," and (2) that the practices were "unlawful." Section 5(a) of the FTC Act makes certain anticompetitive practices unlawful even though they may not be unfair or deceptive to consumers, ${ }^{137}$ but all unfair or deceptive practices are perr se unlawful under section 5(a). Thus the first element of the "actual knowledge" requirement seems to be unnecessary; a defendant who knows that its practice is unfair or deceptive must also know that it is unlawful since section 5(a) prohibits all such practices.

13 FTC v. Morton Salt Co., 334 U.S. 37, 54 (1948); United States v. J.B. Williams Co., 498 F.2d 414, 431 (2d Cir. 1974).

${ }_{133}$ See, e.g., United States v. Ancorp Nat'l Servs., Inc., 516 F.2d 198, 202 (2d Cir. 1975);

United States v. Beatrice Foods Co., 493 F.2d 1259, 1269 (8th Cir. 1974), cert. denied, 420 U.S. 961 (1975).

13645 U.S.C. $\S 45(\mathrm{~m})(1)(B)(2)$ (Supp. V 1975).

13745 U.S.C. $\$ 45(\mathrm{a})(1)(1970)$. 
The independent requirement that the FTC have previously determined a particular practice to be unlawful may provide a reason for the rather peculiar phrasing of the "actual knowledge" requirement. Since a defendant is not subject to penalties unless its practice has previously been held to be unlawful, it seems reasonable to view the knowledge requirement as satisfied if the defendant knew that its practice was unlawful under a prior FTC determination. Such a reading is supported by the conferees' interpretation of similar language in section $5(\mathrm{~m})(1)(\mathrm{A})$, which imposes penalties for rule violations. Section $5(\mathrm{~m})(1)(A)$, like $5(\mathrm{~m})(1)(B)$, contains language that seems to require that a defendant knew or should have known both that its practices were "unfair or deceptive" and that they were prohibited by a Commission rule. However, the Conference Report interpreted this language to require only that the Commission show that the defendant knew that its conduct violated a Commission rule. ${ }^{138}$ The additional burden of showing that the defendant independently knew its practice to be unfair or deceptive was not imposed upon the FTC.

An interpretation that would allow the courts to hold liable only those defendants who "know" that their conduct is deceptive would frustrate enforcement of the Act because it would permit a defendant who happened to disagree with or dislike a particular FTC case to ignore it with impunity. ${ }^{139}$ Nevertheless, the remarks of at least one Congressman appear to support such an interpretation. In discussing the operation of section $5(\mathrm{~m})(1)(\mathrm{B})$, Representative McCollister, a minority conferee from the House, asserted:

[P]enalties cannot be imposed if the defendant in good faith believes that his conduct is permissible. His belief may be based on lack of knowledge of the law or on a reasonable judgment that his circumstances are different from those to whom an order or rule may apply, or indeed on the view, held in good faith, that his conduct is defensible under the FTC Act for any reason. ${ }^{140}$

13 S. REp. No. 93-1408, 93d Cong., 2d Sess. 40 (1974).

133 In an analogous context the Supreme Court has held that ignorance or misapprehension of the law is no defense even under a statute that proscribes only knowing violations. In Hamling v. United States, 418 U.S. 87, 119-24 (1974), the Court ruled that the prerequisite to liability under 18 U.S.C. $\S 1461$ (1970) that the defendant have "knowingly" mailed obscene materials is satisfied by showing that the defendant knew generally of the contents of the materials, without a further showing that he knew the contents fell within the judicial definition of obscenity.

1 140 120 Cong. REc. E7352 (daily ed. Dec. 20, 1974) (emphasis added). 
Although this interpretation drew no rebuttal in the House, its authority is suspect. In the first place it was not made during the course of floor discussion, but was inserted into the Congressional Record after the House had completed action. ${ }^{14 t}$ Second, such an interpretation seems to conflict with the view of Senator Moss, the Act's co-author and its Senate floor manager, regarding good faith. In response to a question concerning the propriety of imposing penalties for continuing violations upon a defendant who claims in good faith that his conduct is lawful, Senator Moss pointed out that under the new law continuing violations would be treated the same as under section $5(l)$ of the Act. ${ }^{142}$ Under section $5(l)$, defendant's good faith is a matter bearing solely on the size of the penalty, not upon the issue of liability. ${ }^{143}$ Indeed, the requirement that a district court in section $5(\mathrm{~m})$ proceedings consider the defendant's "degree of culpability" in determining the amount of penalties ${ }^{144}$ strongly suggests that liability is not to be restricted to bad faith violations.

At the other extreme, some commentators seem to suggest that the actual knowledge requirement is satisfied by a mere showing that the defendant has been exposed to the relevant FTC caselaw. ${ }^{145}$ Under this interpretation, a defendant who had received notice of the relevant decisions would be strictly liable for any violations. Consider the problem facing an advertiser who has been served with a copy of the FTC's decision in R.J. Reynolds Tobacco Co. ${ }^{146}$ In R.J. Reynolds Tobacco Co., the Commission held that it was unlawful

i1 Id. Under the circumstances his remarks should be regarded as representing his personal view only, and not those of the conferees. See National Woodwork Mfrs. Ass'n v. NLRB, 386 U.S. 612,639 n.34 (1967).

H2 120 CONG. REC. 40724 (1974).

13 The only issue in a $\S 5(1)$ civil penalty action is whether the defendant's conduct falls within the terms of a valid Commission order. United States v. J.B. Williams Co., 354 F. Supp. 521 (S.D.N.Y.), rev'd in part on other grounds, 498 F.2d 414 (2d Cir. 1973). Factors other than good faith that are considered in assessing penalties include the extent of public injury, ability to pay, and prior history. See United States v. J.B. Williams Co., 498 F.2d 414, 438 (2d Cir. 1973), and cases cited therein.

is 15 U.S.C. $\$ 45(\mathrm{~m})(1)(C)$ (Supp. V 1975).

is E.g., Comment, Civil Penalties and the Federal Trade Commission Improvements Act, 30 Sw. L. REv. 454, 461-62 (1976); Remarks of Miles J. Kirkpatrick before ABA Section of Antitrust Law, reprinted in 44 ANTrTRUST L.J. 509, 511-12 (1975).

${ }^{116} 46$ F.T.C. 706 (1950), aff'd in part, modified in part, 192 F.2d 535 (7th Cir. 1951), order modified, 48 F.T.C. 682 (1952). The Reynolds decision is one of a number of decisions concerning endorsements and testimonials that have been served on advertising agencies under the FTC's pilot program. The Commission's reliance on Reynolds for the proposition cited in the text may be misplaced. Although the Commission did find that the use of "testimonials" by celebrities who had never smoked the advertised product was deceptive, the only portion of the order relating to testimonials was modified by the court of appeals to prohibiting seven specific claims about the health effects of Camels. No final order was therefore issued "with respect to" the violation found by the Commission, as required by $\S 5(\mathrm{~m})(1)(B)$. 
for an endorser of a product to be represented as using that product when, in fact, the endorser did not use the product. If proof of service of the relevant FTC decision suffices to establish actual knowledge, penalties could be imposed on the offending advertiser even though the advertiser did not anticipate that consumers would interpret the advertisement as implying use by the endorser or even though the advertiser honestly believed that the endorser used the product. ${ }^{147}$

To impose a standard of strict liability upon the defendant advertiser in this hypothetical would be justified if a cease and desist order embodying the R.J. Reynolds principle had been issued against the defendant pursuant to section $5(l) .{ }^{148}$ The legislative history of section $5(\mathrm{~m})$, however, does not support the proposition that defendants not directly subject to a cease and desist order may be held strictly liable.

The language of section $5(\mathrm{~m})$ evolved from a series of earlier attempts to formulate legislation that would enable the Commission to bypass the cease and desist order stage. Section 103 of the Senate Commerce Committee's proposed Consumer Protection Act of 1970 would have authorized the Commission to institute civil penalty actions against persons "knowingly engaged" in practices that had previously been declared unfair or deceptive by Commission rules. ${ }^{149}$ It seems clear that the term "knowingly engaged," as used in section 103, referred to the defendant's knowledge of the deceptive character of its practices. Mere knowledge of the statutory or decisional law of deception would not have sufficed for liability under this formulation, since "knowingly engaged" was defined to include "knowledge presumed where objective circumstances indicate that the [defendant] . . . acted in disregard of reasonable safeguards . . . in ascertaining the truth of representations made." 150 Although this knowledge requirement was revised in subsequent versions of proposed civil penalty legislation to encompass "actual knowledge or knowledge fairly implied on the basis of objective circumstan-

147 Whether a given advertising message constitutes an "endorsement," or a representation that the endorser used the product, turns on whether consumers are "likely to believe" that the message "reflects the experience of a party other than the sponsoring advertiser." Guides Concerning Use of Endorsements and Testimonials in Advertising, 16 C.F.R. § 225.0(b) (1977). The issue is therefore one of fact and the line between an endorser and one who is merely considered a spokesman for the product is a fine one. Compare id., example 3 , with the Commission's proposed Guide 1(c), 40 Fed. Reg. 22147 (1975).

148 See United States v. J.B. Williams Co., 498 F.2d 414 (2d Cir. 1974); United States v.

H.M. Prince Textiles, Inc., 262 F. Supp. 383, 388 (S.D.N.Y. 1966).

11. See text and note at note 24 supra.

150 S. REP. No. 91-1124, 91st Cong., 2d Sess. 24 (1970). 
ces,"151 sponsors of this latter formulation considered it to be "substantially the same" as the knowledge requirement contained in the 1970 version of the proposed Consumer Protection Act. ${ }^{152}$

Thus, at least until the House-Senate Conference in 1974 initially distinguished between rule violations and caselaw violations, nothing in the legislative history suggests that the knowledge requirement could be satisfied simply by showing that the defendant was aware of the relevant legal principles. Indeed the only support for such a conclusion is found in the Senate Commerce Committee report on S. 356, the bill that, after Conference redrafting, became the present section $5(\mathrm{~m}){ }^{153}$ The Committee Report, in explaining the operation of the knowledge requirement with respect to rule violations, ${ }^{154}$ suggested that "a violation of a Commission rule would in most cases constitute a violation 'with knowledge fairly implied from objective circumstances' unless the person against whom the action was brought could show why he should not have been expected to have knowledge of the Commission rule . . . ."155 Even if the report suggests that the defendant's knowledge of the character of its own conduct need not be shown or implied, it does not appear that such a view survived the conference. On the contrary, the Conference Report states that, at least with respect to rule violations, knowledge will be implied "where a reasonable man under the cir-

1st S. 986, 92d Cong., 1st Sess. § 202 (1971); S. 356, 93d Cong., 1st Sess. § 202 (1973).

152117 Cong. REc. 39821 (1971) (remarks of Sen. Moss). Senator Magnuson, the Act's co-author, took pains to emphasize that penalties could be imposed under Title II only for violations "knowingly committed." 117 CoNG. REC. 36910 (1971).

153 S. REP. No. 93-151, 93d Cong., 1st Sess. (1973).

${ }_{15 s} \mathrm{~S} .356$, like its predecessors, made no distinction between violations of FTC rules and violations of caselaw principles. Indeed, any reference in the Senate Commerce Committee Report to rules is puzzling because $\mathrm{S}$. 356 , as reported, included no provision for rulemaking. See text at note 35 supra.

155 S. REP. No. 93-151, 93d Cong., 1st Sess. 27 (1973). The committee may have been thinking of the many trade regulation rules that require that specified disclosures be made, e.g., Failure to Disclose the Lethal Effects of Inhaling Quick Freeze Aerosol Spray Products Used For Frosting Cocktail Glasses, 16 C.F.R. $\S 417$ (1977), or rules that prohibit the use of certain specified terms, e.g., Deceptive Use of "Leakproof", Etc. as Descriptive of Dry Cell Batteries, 16 C.F.R. $\$ 403$ (1977). Knowledge of the provisions of such rules will, as a practical matter, be sufficient, since a seller surely knows whether he is selling products that are subject to the rule. There are other rules, however, for which knowledge of the terms of the rule will rather clearly be insufficient. For example, 16 C.F.R. $\& 432.5$ (1977) (Power Output Claims for Amplifiers Utilized in Home Entertainment Products) broadly prohibits claims where the claimed characteristics "are not obtainable as represented . . . when the equipment is operated by the consumer in the usual and normal manner ...." That a violation of the rule will require knowledge of the falsity of the claim itself is suggested by subsection 6 of the rule, which exempts persons other than manufacturers from liability if they rely on the manufacturer's written certification and are "without actual knowledge of the violation contained in said written certification." 16 C.F.R. $\S 432.6$ (1977). 
cumstances would have known of the existence of the rule and that the act or practice was in violation of its provisions." 156

The Conference Report unfortunately contains no parallel discussion of the knowledge requirement of section $5(\mathrm{~m})(1)(\mathrm{B}) .^{157} \mathrm{Nev}$ ertheless, there is no basis for concluding that Congress intended to impose strict liability upon firms allegedly in violation of caselaw precedents, while permitting rule violators to escape liability who did not know that their conduct violated a rule. Since mere knowledge of the terms of a rule will not satisfy the knowledge requirement for rule violations, mere knowledge of caselaw precedent should not satisfy the knowledge element of section $5(\mathrm{~m})(1)(B)$. If the draftsmen intended such disparate treatment of rule and caselaw violations, ${ }^{158}$ it is odd that they persisted in referring to section $5(\mathrm{~m})$ in its entirety as creating liability for "knowing" violations of both FTC rules and decisions. ${ }^{159}$ Senator Moss, in particular, joined his colleagues in emphasizing that liability for violations of FTC "orders"-caselaw principles-could be imposed only where the violation was "knowing." 160 Therefore, section $5(\mathrm{~m})(1)(B)$ should be interpreted as requiring the Commission to establish that the defendant (1) knew of the prior Commission determination and (2) knew that his practices were unlawful under that determination. ${ }^{181}$

The task of establishing such knowledge will of course vary in difficulty from case to case, but in many instances should not be particularly onerous. In order to show that the defendant knew that his conduct violated an FTC precedent the Commission should not have to establish that the defendant made a conscious legal determination to that effect. The trier of fact will be free to infer such knowledge if the Commission proves that the defendant had actual notice of the relevant caselaw determination. Moreover, the Conference Report provides that the "usual principles of law" that impute the knowledge of responsible corporate officials to the corporation

1s S. REP. No. 93-1408, 93d Cong., 2d Sess. 40 (1974) (emphasis added).

157 The Conference Report does, however, state that "actual knowledge that the act or practice is a violation of the Federal Trade Commission Act is required." Id. This supports the view that the actual knowledge requirement demands both that the defendant knew of the nature of his acts and that they violated a legal determination of the FTC.

${ }_{15 x}$ That FTC decisions, unlike rules, are not published in the Federal Register may explain why "actual knowledge" of the former was required.

135 120 CoNG. REc. 40713 (1974) (remarks of Sen. Magnuson); 120 CoNG. REc. 41406 (1974) (remarks of Rep. Moss).

160120 CoNG. REc. 40712 (1974).

III At the very least $\S 5(\mathrm{~m})(1)(B)$ requires a showing beyond that of the negligence that will satisfy $\S 5(\mathrm{~m})(1)(A)$. See text and notes at notes $167-170$ infra. 
are applicable. ${ }^{162}$ Thus, in a civil penalty action charging the defendant with selling used products as new, the "actual knowledge" requirement should be satisfied by showing directly or through circumstantial evidence that the company's purchasing agents knew the quality of the goods they were buying..$^{163}$

In some cases, however, the utility of section $5(\mathrm{~m})(1)(B)$ as a mechanism for providing effective consumer protection may depend upon how the term "actual knowledge" is defined. When, for example, the meaning of advertisements disseminated by a defendant is at issue, the actual knowledge requirement may form a significant impediment to a successful penalty action. Ordinarily an advertiser's claim that it was unaware of the interpretations placed on an ad by consumers is no defense to an administrative proceeding under section $5(\mathrm{~b})$, which authorizes the Commission to issue cease and desist orders for unfair practices. ${ }^{164}$ Under section $5(\mathrm{~m})$, however, this claim by the advertiser may provide a defense, if the section is interpreted to require the FTC to establish that the defendant knew that its advertisements were understood by consumers in the manner alleged. Similarly, in a penalty action predicated on the defendant's lack of reasonable basis for its claims, the Commission may have to carry more than its administrative burden of showing that the company's reliance on its substantiating material was unreasonable. ${ }^{165}$ It may also have to show that the company or its employees knew that the substantiation was inadequate.

Under section $5(\mathrm{~m})(1)(\mathrm{A})$ the knowledge requirement for rule violations is defined to include "knowledge fairly implied on the basis of objective circumstances," knowledge that a "reasonable and prudent man under the circumstances" would have possessed. ${ }^{166}$ This language implies that liability will attach if the FTC can show that a reasonable man would have known of the existence of a rule and that his acts violated that rule. This phrase, however,

${ }_{162}$ S. REP. No. 93-1408, 93d Cong., 2d Sess. 40 (1974).

${ }_{183}$ Cf. United States v. Dye Constr. Co., 510 F.2d 78 (9th Cir. 1975) (corporation's "willful" violation of $\S 17(\mathrm{e})$ of Occupational Safety and Health Act, 29 U.S.C. $§ 651$ (1970), shown by knowledge of company's back hoe operator that a trench was unstable).

165 See Doherty, Clifford, Steers \& Shenfield, Inc. v. FTC, 392 F.2d 921, 928 (6th Cir. 1968); ITT Continental Baking Co., 83 F.T.C. 865, 968 (1974), aff'd, 532 F.2d 207 (2d Cir. 1976).

185 The Commission has held that even inadequate substantiation may provide a "reasonable basis" if the substantiating material would satisfy a "reasonably prudent businessman." National Dynamics Corp., 82 F.T.C. 488, 553, 557 (1973), aff"d, 492 F.2d 1333 (2d Cir.), cert. denied, 419 U.S. 993 (1974). Under a $\$ 5(\mathrm{~m})(1)(B)$, however, the Government must show more than a lack of due care on the defendant's part.

${ }^{168}$ S. Rep. No. 93-1408, 93d Cong., 2d Sess. 40 (1974). 
was omitted from section $5(\mathrm{~m})(1)(B)$ and there is nothing in either the Conference Report or the floor discussion to explain the disparate treatment of rule violations and caselaw violations. It may seem illogical for Congress to have imposed upon the Commission a heavier burden for establishing violations of its caselaw precedents than for establishing violations of its rules, but the language of section $5(\mathrm{~m})(1)(B)$ does not permit an alternative conclusion.

Although omission of the phrase "knowledge implied on the basis of objective circumstances" indicates that the Commission will carry a heavier burden in $5(\mathrm{~m})(1)(B)$ actions than in rule violation actions, the statute might not exclude liability for "reckless" violations of caselaw precedents. A defendant's reckless disregard is generally considered tantamount to "knowledge" for purposes of common law and securities fraud actions, ${ }^{167}$ but the term "actual knowledge" has also been used to describe a positive consciousness of falsity going beyond recklessness. ${ }^{168}$ Although the "actual" knowledge requirement of section $5(\mathrm{~m})(1)(B)$ can be interpreted to exclude recklessness, it seems more reasonable to view the word "actual" as only excluding liability for negligence. Congress may have specified "actual" knowledge simply to distinguish the $5(\mathrm{~m})(1)(B)$ standard from "constructive" knowledge, a formulation often considered equivalent to a negligence standard, ${ }^{169}$ or from the "implied knowledge" (negligence) standard of $5(\mathrm{~m})(1)(\mathrm{A}) .{ }^{170}$

\section{Status of the FTC's Legal Determinations}

Once the FTC satisfies the district court that a civil penalty defendant's conduct violates an FTC precedent and that the defendant had "actual knowledge," the question arises whether the defendant may argue that its conduct nevertheless did not violate section 5(a) of the Act.

Some commentators have interpreted section $5(\mathrm{~m})(1)(B)$ as a congressional codification of prior Commission caselaw. ${ }^{171}$ If Con-

it See W. Prosser, HandBook of the Law of Torts 701 (4th ed. 1971). For a discussion of the scienter requirement in the context of federal securities regulation, see Bucklo, The Supreme Court Attempts to Define Scienter under Rule 10b-5: Ernst \& Ernst v. Hochfelder, 29 Stan. L. Rev. 213 (1977).

its See United States v. Ekelman \& Assocs., 532 F.2d 545, 548 (6th Cir. 1976) (interpreting the False Claims Act, 31 U.S.C. $\$ 231$ (1970)).

169 See W. LaFave \& A. ScotT, Handbook on Criminal Law 201 (1972).

170 Although $\$ 5(\mathrm{~m})(1)(A)$ speaks in terms of "knowledge fairly implied on the basis of objective circumstances," the Conference Committee interpreted this language as meaning what "a reasonable and prudent man under the circumstances would have known ...." $\mathrm{S}$. REP. No. 93-1408, 93d Cong., 2d Sess. 40 (1974).

${ }^{171}$ Remarks of J. Thomas Rosch before ABA Section of Antitrust Law, reprinted in 44 
gress has incorporated the Commission's caselaw determinations of the statutory prohibition against unfair or deceptive practices into section 5(a), then plainly these determinations are no longer subject to judicial scrutiny. The suggestion that Congress has "codified" all FTC interpretations of "unfair or deceptive" is not, however, supported by the legislative history of section $5(\mathrm{~m})$. Congress may have regarded Commission interpretations of section 5(a) as a welldeveloped and acceptable body of law, but this is hardly equivalent to congressional approval of the thousands of obscure and often contradictory decisions that have been made during the past sixty years. In an analogous context the Supreme Court, in Civil Service Commission v. National Association of Letter Carriers, ${ }^{172}$ declined to view section 15 of the Hatch Act ${ }^{173}$ as codifying "each of the several thousand adjudications of the Civil Service Commission."174 The Court in Letter Carriers did interpret section 15 as adopting eighteen broad principles distilled by the Commission from its decisions, which the Commission had presented to the Congress during the debates on section 15. ${ }^{175}$ The Court, however, held that "only those determinations consistent with the Hatch Act" were intended to be incorporated into section $15,{ }^{176}$ thereby implying that the principles and the Civil Service Commission determinations purporting to apply them would still be subject to judicial review. ${ }^{177}$ The lan-

ANTITRUST L.J. 531, 532 (1975) (Mr. Rosch was then Director of the FTC's Bureau of Consumer Protection); Address of FTC Chairman Lewis A. Engman before ABA Section of Antitrust Law, reprinted in 44 ANTITRUST L.J. 161, 167 (1975).

172413 U.S. 548 (1973). Mr. Rosch referred to the Letter Carriers case in his remarks before the ABA Section of Antitrust Law, supra note 171, at 532.

${ }^{173}$ Hatch Act, ch. $640, \S 15,54$ Stat. 771 (1940) (current version at 5 U.S.C. $\S 7324(a)(2)$ (1970)).

17413 U.S. at 571 . The Court noted that these prior determinations were said to be "undiscoverable, inconsistent or incapable of yielding any meaningful rules to govern future conduct." Id. For a discussion of the problems confronted in dealing with Civil Service Commission determinations, see generally, Rose, A Critical Look at the Hatch Act, 75 HaRv. L. REv. 510 (1962). Similar criticism has been directed at some of the FTC's decisions. See, e.g., Attorney Gen. Comm. on Administrative Procedure, supra note 113 at 441.

175413 U.S. at 572-74.

176413 U.S. at 574 n.19.

17 That the Civil Service Commission's pre-1940 interpretation of the Hatch Act will not necessarily be binding on a court is suggested by the Court's reference to the availability of informal advice from the Commission in order to "remove any doubt there may be as to the meaning of the law, at least insofar as the Commission itself is concerned." 413 U.S. at 580 (emphasis added). The suggestion is in accord with the views of the lower courts and of the Commission itself. When the courts have concluded that the Commission's construction of the Hatch Act was erroneous, they have not hesitated to reverse. In Wilson v. Civil Serv. Comm'n, 136 F. Supp. 104 (D.D.C. 1955), for example, the writing of a letter to the editor attacking a gubernatorial candidate was held not to violate the Hatch Act, even though the pre-1940 Civil Service Commission decisions had prohibited the writing for publication of 
guage of the Hatch Act, moreover, was far more explicit on the issue of codification than is section $5(\mathrm{~m}) ;{ }^{178}$ there is no indication that Congress, in enacting section $5(\mathrm{~m})$, was more than vaguely aware of specific FTC precedents.

A less frivolous argument for foreclosure of district court review of prior FTC legal determinations focuses on the language of the statute. Section $5(\mathrm{~m})(2)$ provides that "issues of fact" are to be tried de novo by the district court if the original cease and desist order was not issued against the defendant in the civil penalty action. It could perhaps be argued that since Congress did not expressly provide for a de novo determination of "legal" issues, the enforcing courts cannot question the validity of the Commission's "legal" determinations. ${ }^{179}$ What little attention was given section $5(\mathrm{~m})(2)$ during the floor debates indicates that the provision was intended

"any letter . . . in favor or against any political party, candidate, faction, or measure." 86 Cong. REc. 2939 (1940). The Commission itself has recognized that it is bound by "currently accepted . . . legal doctrines" even where they collide with the pre-1940 cases. Affidavit of Anthony L. Mondello, reprinted in part in National Ass'n of Letter Carriers v. United States Civil Serv. Comm'n, 346 F. Supp. 578, 599 n.41 (D.D.C. 1972).

${ }^{178}$ Section 15 of the Hatch Act, 5 U.S.C. $\$ 7324(a)(2)$ (1970), defined "active part in political management or . . . campaigns" as those acts "which were prohibited before June 19,1940 , by determination of the Civil Service Commission."

17 "The notion that there exists a neat dichotomy between FTC "factual" and "legal" determinations was refuted over 50 years ago in Gerard Henderson's treatise on the Commission. G. Henderson, The Federal Trade Commission 92-103 (1924). For a more recent treatment of the fact-law distinction in administrative law, see generally K. Davis, ADMINISTRATIVE LAW TrEatise $\S 30$ (1958).

What constitutes a "deceptive practice" is formally considered to be a "legal" question. FTC v. Colgate-Palmolive Co., 380 U.S. 374, 385 (1965). But the question of deception cannot be resolved in a factual vacuum, and the central questions of a representation's meaning to consumers and its "capacity to deceive" are considered "factual." Rhodes Pharmacal Co. v. FTC, 208 F.2d 382, 387 (7th Cir. 1953), rev'd on other grounds, 348 U.S. 940 (1955) (per curiam). Once the FTC has resolved the above "factual" questions against a respondent, the "legal" question of deception is effectively resolved, since the FTC's findings of fact are "conclusive" if "supported by substantial evidence." FTC Act $\S 5$ (c), 15 U.S.C. $\S 45(c)$ (1970). It is almost inconceivable that a court would accept the Commission's factual findings, yet reject its "legal" conclusion of deception. By the same token, it would be unnecessary for a court in a penalty action under $\$ 5(\mathrm{~m})$ to reject the FTC's prior legal determination where the factual hearing guaranteed to the defendant failed to demonstrate that the defendant's advertisements had the meaning charged in the complaint or that they lacked the capacity to deceive.

The discussion of the impact of FTC precedent is not entirely academic, however, because in some instances the effect of the court's acceptance of the FTC's legal theory may be to foreclose a defendant from a factual hearing on some issues. For example, a court's acceptance of the FTC's conclusion that pyramid sales schemes are per se deceptive and unfair would render a hearing on the geographic scope of the scheme or on the nature of the representations made in support of such a scheme unnecessary. Compare Koscot Interplanetary, Inc., 86 F.T.C. 1106 (1975), with Ger-Ro-Mar, Inc. v. FTC, 518 F.2d 33 (2d Cir. 1975), rev'g 84 F.T.C. 95 (1974). 
to preserve and not to restrict the rights of civil penalty defendants who had not been parties to the prior FTC proceeding. ${ }^{180}$ By specifying that these defendants are entitled to a de novo trial of factual issues, it is probable that Congress simply intended to protect such defendants from enforcement of blanket Commission orders that might be inapplicable to their circumstances. It is doubtful that Congress meant in some backhanded fashion to foreclose civil penalty defendants from challenging the FTC's view of the law of deception. Absent clear congressional direction to the contrary, the courts are extremely reluctant to preclude a defendant in an enforcement proceeding from challenging the validity of the government regulation it is charged with violating. ${ }^{181}$ Neither the language nor the history of section $5(\mathrm{~m})(2)$ establishes such clear congressional directive.

On the contrary, there is affirmative evidence that FTC determinations may be subjected to judicial scrutiny in the course of an enforcement proceeding. Congress has taken pains to ensure that a defendant charged with violation of an FTC rule-and such violations are now violations of the Act ${ }^{182}$-may challenge the validity of that rule as a defense to a civil penalty proceeding even though the validity of the rule may also be challenged in a preenforcement action in a court of appeals. ${ }^{183}$ Prior to the enactment of the Magnuson-Moss Act, many FTC caselaw precedents, as opposed to FTC rules, were not subject to judicial review. ${ }^{184}$ It is hard to believe that Congress, having taken great care to provide multiple avenues of review for defendants charged with rule violations, intended to close all avenues of review to defendants charged with transgressing "rules" developed through adjudication.

180120 CoNG. REc. 41407 (1974) (remarks of Rep. Broyhill).

Ix! See Johnson v. Robinson 415 U.S. 361 (1974); Estep v. United States, 327 U.S. 114, 120-23 (1945).

$1 \times 215$ U.S.C. $\$ 57 \mathrm{a}(\mathrm{d})(3)$ (Supp. V 1975).

$1 \times$ Section 18(e)(5)(B) of the Act, 15 U.S.C. $\$ 57 a(e)(5)(B)$ (Supp. V 1975) grants to the courts of appeal "exclusive jurisdiction of any action to obtain judicial review (other than in an enforcement proceeding) of a rule prescribed under 15 U.S.C. $\$ 57 \mathrm{a}(\mathrm{a})(1)(B) . "$ Without the parenthetical recognition of the authority of the enforcement court it could have been argued that Congress had intended to make preenforcement review the exclusive avenue for challenging the validity of the rule. For such a construction, see Weinberger v. Bentex Pharmaceuticals, Inc., 412 U.S. 645, 651-52 (1973).

${ }^{1 s}$ Section 5(c) of the Act, 15 U.S.C. \$ 45(c) (1970), has been interpreted to permit only the petitioner against whom an order has been issued to seek review. Consumer Fed'n of America v. FTC, 515 F.2d 367, 370 (D.C. Cir. 1975). In many cases containing important FTC determinations, review on behalf of a petitioner is foreclosed because the petitioner chose not to contest the FTC's assertions in the course of the administrative proceeding. See, e.g., National Candy Co. v. FTC, 104 F.2d 999, 1006 (7th Cir.), cert. denied, 308 U.S. 610 (1939). 
A further indication that caselaw determinations, like rules, are subject to review in the context of a civil penalty proceeding appears in the floor discussion between Senators Taft and Moss. ${ }^{185}$ Senator Moss explained that the apparent harshness of section $5(\mathrm{~m})(1)(\mathrm{C})$, which authorizes daily penalties for continuing violations, is mitigated by the authority conferred upon the courts by section 10(d) of the Administrative Procedure Act ${ }^{186}$ to order a stay of penalties if there is a "testing" of the "legality of a particular action or a particular rule ...." ${ }^{187}$ Although Senator Moss erroneously assumed that the courts had traditionally granted such stays in civil penalty proceedings under section $5(l)$ of the FTC Act, ${ }^{188}$ it seems clear that by "a particular action" the Senator meant FTC cease and desist adjudications.

That prior FTC decisions will be subject to judicial review in an enforcement proceeding does not mean that these precedents will be accorded no weight. Indeed, in discussing the scope of review of FTC rules, the House-Senate Conference stated that courts would apply "the established principle pursuant to which courts give weight to interpretations by expert agencies of the laws such agencies were created to administer and enforce."189 FTC caselaw determinations should be entitled to the same deference. The Supreme Court has recognized that the Commission's interpretations of section 5 should be accorded "great weight" by reviewing courts. ${ }^{190}$ Courts likely will give enhanced weight to prior FTC determinations that have withstood judicial review. ${ }^{191}$ Thus, even though a defendant will not be "bound" in the res judicata sense by prior FTC and judicial decisions to which it was not a party, successful challenges to FTC precedents will probably be rare. ${ }^{192}$

$1 \mathrm{ss}$ See note 142 supra.

185 U.S.C. $\$ 705$ (1970).

เ\$7 120 CONG. REC. 40724 (1974).

Isx See id.

18s S. REp. No. 93-1408, 93d Cong., 2d Sess. 35 (1974).

190 Atlantic Ref. Co. v. FTC, 381 U.S. 357, 367-68 (1963) (citing FTC v. Cement Inst. 333 U.S. 683, 720 (1948); NLRB v. Hearst Publications, Inc., 322 U.S. 111, 131 (1944)). That this "established principle" has frequently been honored in the breach (see K. Davis, AdministraTIVE LAW OF THE SEVENTIES \$ 30.00, at 688-93 (1976)) does not mean that it should be ignored.

'11 Although the Conference Report did not address the issue, the Senate Commerce Committee report on $S .356$, the predecessor of the present $\$ 5(\mathrm{~m})$, recognized that judicial review of FTC rules might be restricted for "judicial reasons, e.g., Stare decisis or res adjudicata." S. REP. No. 92-269, 92d Cong., 1st Sess. 28 (1973). By the same token, the Commission will be taking its chances in the district court when it relies on caselaw precedents not themselves subject to judicial review, but which are similar to Commission decisions that have been reversed on appeal.

132 As I have suggested in note 179 supra, disagreements with the Commission are more likely to center on its resolution of factual disputes than on its broad pronouncements on the 


\section{Preenforcement Relief}

Although the validity of an FTC precedent may be challenged by a defendant in its defense to a penalty action, this right should not necessarily preclude the availability of preenforcement declaratory relief. Abbott Laboratories $v$. Gardner ${ }^{193}$ suggests that preenforcement review will be available, even in the absence of a specific statutory provision, when the impact on a potential defendant's behavior is likely to be substantial. Like the impact of an FTC rule, the impact of an FTC caselaw precedent is quite substantial. A firm subject to FTC jurisdiction must either conform its conduct to the dictates of FTC case determinations or run the risk of incurring sizeable penalties.

The discretion granted to the district court under section $5(\mathrm{~m})(1)(\mathrm{C})$ to reduce the penalty or to stay the running of penalties during a good faith challenge to the validity of the FTC precedent ${ }^{194}$ may ease the defendant's plight. Nevertheless, the courts have made preenforcement review available under other statutory schemes, even where such risk-reducing devices were available. In Ford Motor Co. v. Coleman, ${ }^{195}$ a three-judge district court held that preenforcement review was available to test the validity of administrative determinations made under the National Traffic and Motor Safety Act of $1966,{ }^{196}$ even though Congress had failed to provide for such review and the maximum statutory penalties were not cumulative. ${ }^{197}$ Although some courts have refused to grant preenforcement review to defendants faced with penalties under section $5(l)$ of the FTC Act, those cases involved challenges to the interpretation of orders of unquestioned validity. ${ }^{198}$

law. These factual issues will, of course, generally remain open to relitigation in the enforcement proceeding.

${ }^{193} 387$ U.S. 136, 152-53 (1968).

19: See text and note at note 186 supra.

195402 F. Supp. 475 (D.D.C. 1975) (three-judge court), aff'd mem., 425 U.S. 927 (1976).

19615 U.S.C. $\$ \S 1397(a)(1)(D), 1398,1412$ (a), 1415(b) (Supp. V 1975).

197 The maximum penalty for any "related series of violations" of the Act was $\$ 800,000$. 15 U.S.C. $\$ 1398$ (a) (Supp. V 1975). In contrast, it is arguable that a separate $\$ 10,000$ penalty for violations of the FTC Act may be imposed both for each day the violation occurs and for each copy of the offending advertisement. See United States v. Golden Fifty Pharmaceutical Corp., 421 F. Supp. 1199, 1207 (N.D. Ill. 1976) (dictum). The resulting liability under such a calculation may be staggering. For example, the six cigarette companies charged with violating an FTC order have argued that each company's liability for a single advertisement placed in the New York Daily News was potentially $\$ 30$ billion. Brown \& Williamson Tobacco Corp. v. Engman, 527 F.2d 1115, 1119 n.7 (2d Cir. 1975), cert. denied, 426 U.S. 911 (1976).

18* See, e.g., Brown \& Williamson Tobaćó Corp. v. Engman, 527 F.2d 1115 (2d Cir. 1975), cert. denied, 426 U.S. 911 (1976). In refusing to enjoin the accumulation of the penalties for alleged violations of a consent order, the Second Circuit noted that any challenge to the 
In Consumer Federation of America $v$. FTC, ${ }^{199}$ a court of appeals found "clear and convincing evidence" in the language of section 5(c) of a congressional intent to limit judicial review of FTC cease and desist orders to the companies named in the order. In Consumer Federation two consumer groups sought review of the FTC's failure to adopt a "corrective advertising" remedy urged by the groups against a company found to have engaged in false advertising. ${ }^{200}$ The court dismissed for lack of jurisdiction, reasoning that the consumer groups were no different from individual or corporate complainants whom Congress had intended to foreclose from appealing FTC failure to prohibit particular practices. ${ }^{201}$ The legislative history relied upon by the court in Consumer Federation ${ }^{202}$ did not, however, address the new problems raised by section $5(\mathrm{~m})$. In limiting the availability of review of FTC cease and desist orders to the addressees of such orders, Congress could not have anticipated that cease and desist orders might have an immediate impact on the conduct of non-parties. Pre-1975 FTC decisions had some precedential impact on subsequent FTC proceedings, but until 1975 a company not named in the Commission's order could violate the announced principle with impunity. Absent a far clearer indication than that provided by the 1914 debates on the original FTC Act, ${ }^{203}$ the principle of Consumer Federation should not be extended to deny preenforcement relief to prospective section $5(\mathrm{~m})$ defendants. ${ }^{204}$

validity of the order had been waived in the consent agreement, so that only the question of the order's interpretation remained. The court assumed that had an issue as to the order's validity been presented, preenforcement review would be available pursuant to 15 U.S.C. $\S$ 45(c) (1970). 527 F.2d at 1119. Moreover, in Floersheim v. Engman, 494 F.2d 949 (D.C. Cir. 1973), the court dismissed a preenforcement challenge to the FTC's interpretation of an order primarily because the challenge had been brought in the wrong forum. Because the order in question had been affirmed by the court of appeals in a different circuit, the court held that any proceeding for clarification of the order could be maintained only before the court that had affirmed the order. Although the court suggested that preenforcement review would be appropriate only in "rare" instances, $i d$., it did not foreclose the possibility of such review in an appropriate case.

139 515 F.2d 367, 373 (D.C. Cir. 1975).

200 The Commission's order was ultimately affirmed, with modifications, in ITT Continental Baking Co. v. FTC, 532 F.2d 207 (2d Cir. 1976).

201515 F.2d at 373.

${ }^{202} 51$ Cong. Rec. 12993, 13044-66, 13102-11, 13315-19, 14765-66 (1914).

${ }^{200}$ Id.

201 The holding in Consumer Federation is probably correct, but it is questionable whether judicial review of FTC orders would be strictly limited to those named in the orders, even without the enactment of $\$ 5(\mathrm{~m})$. In Pepsico, Inc. v. FTC, 472 F.2d 179 (2d Cir. 1972) (dictum), cert. denied, 414 U.S. 876 (1973), Judge Friendly, speaking for a divided court of appeals, suggested that bottling companies that had exclusive territorial agreements with Pepsico would be entitled to review of any cease and desist order that might be entered 
The legislative history surrounding the enactment of section $5(\mathrm{~m})$ does not reveal a congressional intent to foreclose preenforcement review. Indeed, the only evidence to be found arguably suggests that some form of review was expected. In response to expressions of fear that the scheme of section $5(\mathrm{~m})$ might unfairly deter good faith challenges to FTC lawmaking, Senator Moss remarked that the courts would stay the running of penalties when the validity of a Commission precedent is the subject of a good faith dispute. ${ }^{205}$ Although Senator Moss's remarks appear to have been concerned primarily with the powers of the enforcement court, his reference to section $10(\mathrm{~d})$ of the Administrative Procedure Act ${ }^{206}$ as the source of the stay authority ${ }^{207}$ suggests that some opportunity for preenforcement review was contemplated as well.

The availability of preenforcement declaratory relief does not mean that the FTC must now be prepared to defend each of the thousands of deceptive practices decisions it has issued over the past sixty years. In the first place, although the factual findings made by the Commission in some of its cases have been criticized, ${ }^{208}$ most of the general legal principles it has announced are beyond serious dispute, and have long since been recognized by the courts. Second, although there are undoubtedly many old and rather obscure FTC decisions that have never been subjected to judicial scrutiny, the likelihood that the Commission will seek to enforce the principles underlying these decisions through penalty actions may not be sufficiently great to warrant judicial intervention. It may be reasonable to presume that when an agency has recently committed substantial resources to promulgating a rule, it stands ready to commit the additional resources to enforce it. ${ }^{209}$ But it is not reasonable

against Pepsico, even though the bottlers had not been joined in the FTC's complaint and would not therefore be formally subject to the order. Id. at 185-86. Judicial review, the majority held, would be required because the bottlers would effectively be bound by a final order enjoining Pepsico from enforcing its exclusive contracts and the bottlers' rights to exclude competitors from their territories would thereby be impaired. Id. at 190-91. Judge Medina dissented from the majority's refusal to enjoin the FTC's administrative proceeding for failure to join the bottlers as indispensible parties, in part because he believed that the bottlers would otherwise not have been entitled to judicial review. Id. at 193.

20: 120 CONG. REC. 40724 (1974).

${ }^{208} 5$ U.S.C. $\$ 705$ (1970).

${ }^{207} 120$ CoNG. REC. 40724 (1974).

20x Most of this criticism has been directed at the FTC's interpretation of advertising claims in a manner thought overly protective of consumers. See, e.g., G. ALEXANDER, HONESTY AND Competition 6-9 (1967); Millstein, The Federal Trade Commission and False Advertising, 64 Colum. L. Rev. 439 (1964).

209 See K. Davis, supra note 190, at 470 . For perhaps the strongest assertion of this view, see Vining, Direct Judicial Review and the Doctrine of Ripeness in Administrative Law, 69 MrCH. L. REv. 1443 (1971). 
to presume that the FTC stands equally ready to enforce each of the thousands of "determinations" it has made during the past sixty years. Although it is difficult to draw this line, ${ }^{210} \mathrm{I}$ believe that relief ordinarily would be unwarranted, at least until the FTC serves a copy of the precedent on the party seeking review. Although service of the precedent may not be necessary to demonstrate a company's "actual knowledge," the difficulty of independently demonstrating such knowledge makes it unlikely that the Commission would seek to recover penalties for practices occurring before service. If the party seeking relief has been served with the FTC precedent, however, the court has concrete evidence that the Commission has decided to commit enforcement resources to vindicating the principle announced in the precedent.

Finally, even when the Commission has announced its readiness to enforce a prior precedent, questions of ripeness remain. In Abbott Laboratories the Supreme Court concluded that the controversy over the FDA regulation at issue was ripe for review, in part because "the issue tendered [was] a purely legal one ...."211 Whether a given practice is "unfair" or "deceptive" is generally considered to be a "legal question," but the conclusion often will turn on the resolution of specific facts peculiar to the plaintiff's conduct. Even if the Commission has adopted a per se principle, as it did when it held that there must be a reasonable basis for all "affirmative product claims," 212 a court may still decline to entertain an attack on the principle in the abstract, without considering the specific advertising claims at issue or the company's substantiation for the claims. Although a court in a declaratory judgment action is certainly capable of resolving factual issues, such as the interpretation that consumers would likely give an advertisement, it may wish to defer resolution to the enforcement proceeding so that, if the company desires, a jury might decide the issue. ${ }^{213}$

${ }^{210}$ The mere existence of an FTC precedent, like the existence of a statute making certain conduct illegal, may not be sufficient to demonstrate that a "case or controversy" exists. Compare Doe v. Bolton, 410 U.S. 179, 188-89 (1973) (4-year old statute, which replaced a previous statute under which a number of prosecutions has been brought), with Poe v. Ullman, 367 U.S. 497 (1961) (80-year old statute with one prosecution).

211387 U.S. at $148-49$.

${ }_{212}$ See National Dynamics Corp., 82 F.T.C. 488,557 (1973).

${ }^{213}$ Cf. United States v. J.B. Williams Co., 498 F.2d 414, 429-30 (2d Cir. 1974) (jury has "more experience than most judges" in determining the meaning of an advertisement). The holding in J.B. Williams that the seventh amendment right to jury trial attaches in a civil penalty proceeding under $\S 5(l)$ of the FTC Act would appear equally applicable to actions under $\$ 5(\mathrm{~m})$. 


\section{INTERVENTION}

Under both section 5(b) of the FTC Act and the Commission's rules intervention by a non-party in an adjudicative proceeding may be permitted as a matter of FTC discretion. ${ }^{214}$ If the Commission's decisions were to be considered "binding" on non-parties, a strong argument could be made that intervention must be allowed, particularly when the non-parties' interests are inadequately represented in the proceeding. ${ }^{25}$ In Pepsico, Inc. v. FTC, ${ }^{216}$ the Second Circuit, applying the principles of rule 24(a) of the Federal Rules of Civil Procedure, held that a person whose contract rights might be impaired by orders entered in a Commission proceeding against another has a right to intervene in that proceeding. If an FTC caselaw principle, however, is subject to challenge by a section $5(\mathrm{~m})$ defendant who was not a party to the original administrative proceeding, ${ }^{217}$ such intervention should be unnecessary. To be sure, a Commission decision against company $A$ may ultimately be a precedent in a subsequent penalty action against company $B$, but the precedential value of the first decision is probably insufficient to establish an interest in the subject matter of the prior administrative proceeding such that $B$ could intervene as of right under the principles of rule 24(a). ${ }^{218}$ The effect of the Commission's decision extends beyond ordinary precedent in the sense that it creates a threat of penalties where no threat may have existed previously. The grant

${ }^{214}$ FTC Act $\$ 5(b), 15$ U.S.C. $\$ 45(b)$ (Supp. V 1975) provides: "Any person, partnership, or corporation may make application, and upon good cause shown may be allowed by the Commisson to intervene and appear in said proceeding ...." Section 3.14 of the FTC's rules provides: "The admnistrative law judge or the Commission may by order permit the intervention to such extent and upon such terms as are provided by law or as otherwise may be deemed proper." 16 C.F.R. § 3.14 (1977).

${ }^{215}$ See Comment, Civil Penalties and the Federal Trade Commission Improvements Act, 30 Sw. L. REv. 454, 472-74 (1976).

${ }_{216}^{216}$ F.2d 179, 184 (2d Cir. 1972), cert. denied, 414 U.S. 876 (1973).

217 See Section IV, supra.

${ }^{21 k}$ See Great Atl. \& Pac. Tea Co., 83 F.T.C. 1356, 1357 (1974); Shapiro, Some Thoughts on Intervention Before Courts, Agencies and Arbitrators, 81 HARv. L. REv. 721, 729-34 (1968). Although some courts have held that the stare decisis effect of a judgment may in some instances be sufficient to satisfy the requirements of rule $24(\mathrm{a})$, the circumstances have been unusual. For example, in Atlantis Dev. Corp. v. United States, 379 F.2d 818 (5th Cir. 1967), an action to establish ownership of offshore land, the ability of the intervenor, who also claimed an interest in the land, would have been impaired by a judgment for either party since any subsequent action would have to have been brought in a district court within the same circuit and the decision of the court of appeals in the first case would have been controlling. In Nuesse v. Camp, 385 F.2d 694 (D.C. Cir. 1967), the subsequent action could conceivably have been brought in a different circuit, but the applicant for intervention, the state banking commissioner, had a peculiar interest in the subject matter of the litigation, and was therefore permitted to intervene. 
of amicus curiae status to company $B$ should normally suffice to protect $B$ 's interests, since $B$ remains free to relitigate the factual questions before the enforcement court. ${ }^{219}$

\section{Conclusion}

Section $5(\mathrm{~m})(1)(B)$ was the byproduct of a legislative process that focused primarily on other more controversial provisions. In its present form it appears to have been slapped together as an afterthought, and its authors seem to have had only a vague idea of how it was to be applied. Ambiguity and contradiction pervade its language and the congressional debates accompanying its enactment. Subsequent commentary has regarded section $5(\mathrm{~m})(1)(\mathrm{B})$ as an "unsprung bear trap"220 that converts each FTC cease and desist order into a new rule of law binding both potential defendants and the courts. As a result, the legislation has given rise to unrealistic expectations and exaggerated fears.

This article has taken a more modest view. First, there seems to be a continuing role for the courts, as well as the Commission, in giving substance to section 5's sweeping prohibition of unfair or deceptive practices. In my view, the new status conferred upon FTC interpretations made in administrative proceedings serves primarily to shift responsibility for enforcement of the Act from the Commission to the courts, but does not relieve the courts of their obligations to ensure that the Commission's interpretations of the Act are justifiable. Second, unlike some commentators, ${ }^{221} \mathrm{I}$ believe that the "actual knowledge" prerequisite to section 5(m)(1)(B) civil liability may impose a significant hurdle to successful prosecution of many penalty actions.

The issues identified in this article will not be speedily resolved. The FTC has barely begun its enforcement program under the new Act, and few of the lurking issues are likely to be judicially resolved in the near future. Despite its shortcomings and uncertainties, section $5(\mathrm{~m})$ will be a potent weapon in the FTC's consumer protection arsenal. Whether it will be used with vigor, imagination, and fairness remains to be seen.

210 15 U.S.C. $\$ 45(\mathrm{~m})(2)$ (Supp. V 1975).

20 Remarks of Caswell O. Hobbes before ABA Section of Antitrust Law, reprinted in 45 ANTITRUsT L.J. 103, 113 (1976).

221 See, e.g., Remarks of Lee N. Abrams before ABA Section of Antitrust Law, reprinted in 44 ANTITRUST L.J. 523, 524-25 (1975). 